\title{
TRENDS IN SELF-EMPLOYMENT AMONG WHITE AND BLACK MEN:
}

$1910-1990$

\author{
Robert W. Fairlie \\ Bruce D. Meyer
}

Working Paper 7182

http://www.nber.org/papers/w7182

\section{NATIONAL BUREAU OF ECONOMIC RESEARCH \\ 1050 Massachusetts Avenue \\ Cambridge, MA 02138 \\ June 1999}

We would like to thank Joseph Altonji, Rebecca Blank, Thomas Dunn, Lori Kletzer, Ivan Light, Rebecca London, Derek Neal, Roger Ransom and participants at the 1997 Winter Meetings of the Econometric Society, the All-UC Group in Economic History Conference at University of California, Davis, the Bay Area Labor Economists Workshop at San Francisco State University, and the OECD/CERF/CILN International Conference on Self-Employment for their comments. We would also like to thank Brian Jenn, Chris Jepsen and Dan Rosenbaum for their research assistance. All opinions expressed are those of the authors and not those of the National Bureau of Economic Research.

(C) 1999 by Robert W. Fairlie and Bruce D. Meyer. All rights reserved. Short sections of text, not to exceed two paragraphs, may be quoted without explicit permission provided that full credit, including (C) notice, is given to the source. 
Trends in Self-Employment Among

White and Black Men: 1910-1990

Robert W. Fairlie and Bruce D. Meyer

NBER Working Paper No. 7182

June 1999

JEL No. J0, J4

ABSTRACT

We examine trends in self-employment among white and black men from 1910 to 1990 using Census and CPS microdata. Self-employment rates fell over most of the century and then started to rise after 1970. For white men, we find that the decline was due to declining rates within industries, but was counterbalanced somewhat by a shift in employment towards high selfemployment industries. Recently, the increase in self-employment was caused by an end to the within industry decline and the continuing shift in employment towards high self-employment industries. We find that the trends in self-employment average returns do not easily explain the decline in self-employment from 1950 to 1970 , nor the increase from 1970 to 1990. We also find that changes in tax rates, social security benefits, and immigration patterns do not explain the recent upturn in self-employment. For black men, we find that the self-employment rate remained at a level of roughly one-third the white rate from 1910 to 1990 . The large and constant gap between the black and the white rates is not due to blacks being concentrated in low self-employment rate industries, but is consistent with job opportunities outside of self-employment increasing relative to those in self-employment. However, more recently the relative earnings of blacks in self-employment rose more than relative earnings for whites, making the near constancy of the relative self-employment rates more surprising. We also find that absent continuing forces holding down black selfemployment, a simple inter-generational model of self-employment suggests that black and white rates would converge quickly.

Robert W. Fairlie

Department of Economics

Social Sciences I

University of California

Santa Cruz, CA 95064

rfairlie@cats.ucsc.edu
Bruce D. Meyer

Department of Economics Northwestern University

2003 Sheridan Road

Evanston, IL 60208

and NBER

bmeyer@nwu.edu 


\section{Introduction}

The decline in self-employment during this century is one of the major historical trends in the U.S. labor market. The fraction of white male workers who were self-employed fell from one in six in 1910 to one in ten in 1970. It is also striking that this trend stopped and reversed itself between 1970 and 1990. The self-employment rate rose from 10.0 percent in 1970 to 11.4 percent in 1990. Given the magnitude of these changes in self-employment, surprisingly very little research has documented the changes and identified their causes. Trends in black selfemployment have been studied even less, despite much recent interest in the lack of black-owned businesses and frequent conjectures about historical levels of self-employment and their causes. We use Census microdata covering most of the twentieth century to document the trends in selfemployment among both white and black men and to explore their potential causes.

An examination of long-term trends in self-employment is important for several reasons. First, it has been argued that small businesses create a disproportionate share of new jobs in the economy, are an important source of innovation, and have an important effect on political decisions in the United States. ${ }^{1}$ Second, many academicians and policy makers view selfemployment as a route out of poverty and as an alternative to unemployment or potential discrimination in the labor market. ${ }^{2}$ Third, the institutional environment in which the selfemployed work differs in important ways from that of wage/salary workers. The self-employed are not subject to the usual labor contracts and their consequent incentives, and they either do not receive, or purchase for themselves, fringe benefits provided by employers, such as health

\footnotetext{
${ }^{1}$ For example, see Birch (1979) for job creation, and Glazer and Moynihan (1970) and Brown, Hamilton, and Medoff (1990) for political power. Also, see "Small Product-development Firms Show Solid Growth; Entrepreneurs Fill a Void as Big Concerns Trim Their Internal R\&D Staffs," Wall Street Journal, April 22, 1997, p. B2, "For New Jobs, Help Small Businesses," Wall Street Journal, August 10, 1992, p. A12, "New York City Is Looking to Small Businesses to Provide Jobs," New York Times, May 3, 1993, p. B12, "Start-up Firms Can Balance Downsizing, Create Jobs," Los Angeles Times, February 14, 1993, p. D1, Job Growth Stalls, Despite Recovery, as Many Small Businesses Stop Hiring," Wall Street Journal, February 12, 1993, p. A2.

${ }^{2}$ See Glazer and Moynihan (1970), Light (1972, 1979), Sowell (1981), and Moore (1983). Also, many states and the federal government are currently promoting self-employment as a way to leave the welfare and unemployment insurance rolls. For descriptions of these programs see Guy, Doolittle, and Fink (1991) and Raheim (1997) for the AFDC program, and U.S. Department of Labor (1992) and Benus et al. (1995) for the UI program.
} 
insurance and pensions. Past research has argued that the self-employed have a different return to education, will have a different age-earnings profile, and have more variability in hours worked than wage/salary workers. ${ }^{3}$ Finally, the self-employed are often singled out in the formation of public policy. They are treated differently in various aspects of the tax code and are frequently excluded from social insurance programs.

Past studies have examined trends in white or total self-employment during various periods of the twentieth century, however, these studies have generally been limited by their reliance on published aggregate data and their use of a short time period. ${ }^{4}$ Several social scientists near the middle of this century, most notably Weber (1947), C. Wright Mills (1951) and Phillips (1962) documented the decline in self-employment over the first half of the century and predicted that it would continue to decline. ${ }^{5}$ A few studies have focused on the recent rise in selfemployment; only one of these studies, however, includes an empirical analysis of its potential causes. Blau (1987) finds that changes in technology, industrial structure, tax rates, and social security retirement benefits contributed to the rise in self-employment from 1973 to 1982 . We test these explanations using Census microdata covering a longer time period.

Although several recent studies have documented and analyzed the causes of the alarmingly low rate of self-employment among blacks in the U.S., none of these studies have examined the trend over the twentieth century. ${ }^{6}$ In the past few years, many news articles and editorials have referred to estimates from the Survey of Minority-Owned Business Enterprise (SMOBE) which show a large increase in the number of black-owned businesses over the last 20

${ }^{3}$ See Wolpin (1977), Lazear and Moore (1984), and Rettenmaier (1996).

${ }^{4}$ See Phillips (1962) for 1929-60, Bregger (1963) for 1948-62 and updates by Ray (1975), Fain (1980) and Becker (1984), Blau (1987) for 1948-82, and Aronson (1991) for 1955-88.

${ }^{5}$ The clearest statement comes from Phillips (1962, p. 1) who reports that "...the proportion of self-employed persons in the American labor force has been declining for many decades. This trend will no doubt persist in the future."

${ }^{6}$ See Bates (1987, 1989), Borjas and Bronars (1989), Meyer (1990), Fairlie (1996, 1999), and Fairlie and Meyer (1996). 
years. $^{7}$ Estimates that we present in this paper, however, do not lend support to this finding and instead suggest that the black self-employment rate has not changed relative to the white selfemployment rate over the last 20 years or, for that matter, over the last 80 years. ${ }^{8}$ The issue of convergence in racial self-employment rates is of special interest because many early researchers emphasized the role that past inexperience in business played in creating low rates of business ownership among blacks. In particular, Du Bois (1899), and later Myrdal (1944), Cayton and Drake (1946) and Frazier (1957) identify the lack of black traditions in business enterprise as a major cause of low levels of black business ownership at the time of their analyses. We create and employ a simple intergenerational model of self-employment to simulate how quickly the initial condition of low black self-employment in the past would have faded if there were no other factors depressing black self-employment.

Using Census microdata, we first examine potential causes of the long-term decline in the white male self-employment rate from 1910 to 1970 and the reversal of this trend after 1970. We also briefly examine recent Current Population Survey data to confirm some of our results. The main findings from this analysis are:

1) We do not find strong support for a few recently proposed explanations for the rise in selfemployment. (a) The long-term pattern of tax rate changes, as well as the1970-90 pattern does not accord well with the change in self-employment rates. (b) Self-employment has risen sharply even for those groups unlikely to be affected by social security retirement incentives. (c) Changes in immigration patterns or immigrant self-employment rates cannot explain a significant portion of the recent upturn in self-employment for whites.

2) A simple model of sectoral choice in which self-employment rates are determined by relative earnings in self-employment and wage/salary work cannot explain the decline in self-employment from 1950 to 1970 , nor the increase from 1970 to 1990.

\footnotetext{
${ }^{7}$ See "Black-Owned Firms in U.S. Are Increasing at Rapid Rate," Wall Street Journal, September 12, 1990, p. B2, "Black Business Ownership Up," New York Times, September 13, 1990, p. D5, and "Black Firms Increasing in Number," Washington Post, September 12, 1990, p. C1.
}

${ }^{8}$ See Appendix A for a comparison of our estimates of white and black self-employment rates to those from other data sets. 
3) The long-term decline in the self-employment rate reflects declining rates within nearly all industries. Technological change favoring capital-intensive, large-scale production may be responsible for this trend. The long-term decline, however, was weakened somewhat by a shift in total employment towards high self-employment industries.

4) The recent increase in the self-employment rate was caused by an end to the overall decline in self-employment within industries and the continuing shift of overall employment from low selfemployment industries, such as manufacturing, towards high self-employment industries, such as construction, professional, and business and repair services. We also find offsetting increases and decreases in self-employment across a few industries. These findings are consistent with changes in consumer demand, increased global competition, and changes in technology driving the recent upturn in self-employment.

We also explore the factors contributing to the trend in the black male self-employment rate. We focus on the trend in black self-employment relative to white self-employment. The main findings from this analysis are:

1) The self-employment rate of black men relative to white men has remained roughly constant from 1910 to 1990 (at a level of approximately one third the white rate).

2) The large gap between the black and the white self-employment rates is due to the lower selfemployment rates of blacks in all industries and not due to the concentration of blacks in low selfemployment rate industries.

3) From 1950 to 1990, the earnings of blacks in self-employment relative to wage/salary work rose more than relative earnings for whites, making the near constancy of the black/white ratio of self-employment rates more surprising.

4) We find that major demographic changes that occurred during the twentieth century, such as the Great Black Migration and the racial convergence in educational attainment, did not have large effects on the racial self-employment rate gap.

5) Evidence from simulations using a simple intergenerational model of self-employment suggests that, if not for continuing factors reducing black self-employment, racial convergence in selfemployment rates would occur within a few generations.

6) Low levels of, and a slow rate of growth in, black assets relative to white assets over the past three decades may have contributed to the lack of racial convergence in self-employment rates.

\section{Data}

This study uses individual data from seven decennial Censuses of Population: 1910, and 1940 through 1990. A public use sample is not currently available for the 1930 Census, and only 
a preliminary version of the 1920 Census sample exists. ${ }^{9}$ We use random samples of the population for each year to obtain approximately 40,000 individuals of each race if more than that many are available. ${ }^{10}$ Further details and the exact samples used are provided in Appendix B. The Current Population Survey data that we briefly examine at the end of the paper are described in Section 5 .

Our Census microdata have two major advantages over other data sources for this analysis. First, each Census provides a sample large enough to examine self-employment rates and/or earnings within fairly detailed race, industry, age, education and region categories. This detail also allows us to conduct multivariate analyses of the determinants of racial differences in self-employment. Second, this collection of Census data allows us to analyze racial selfemployment patterns from near the beginning of the twentieth century to the present.

The final sample that we use for each of the Census years only includes respondents who meet several restrictions. First, we only include men in this analysis because the study of female self-employment is complicated by overall changes in labor force participation, education, and fertility of women that are beyond the scope of this paper. Second, consistent with previous studies of self-employment, we exclude individuals who work in agriculture. Third, we restrict our samples to include individuals who are between the ages of 16 and 64 (unless noted otherwise) and who report working at least 15 hours during the week prior to the interview and at least 14 weeks during the year prior to the interview. In 1910, however, we do not impose the hours and weeks worked restrictions because these variables are not available.

We distinguish between self-employment and wage/salary work based on the individual's response to the class of worker question found on each of the included Censuses. The selfemployed in our study are those individuals who report primarily being an employer, working on own account, or being self-employed with own incorporated or not incorporated business. For example, in 1990 the relevant choices on the Census questionnaire were 6) "SELF-EMPLOYED

\footnotetext{
${ }^{9}$ The final version of the 1920 Census will be a 1 percent sample and will be released this year.

${ }^{10}$ For the 1910, 1940, 1950, 1960, and 1970 Censuses we are limited to 5057, 14715, 6934, 27054, and 35627 black men, respectively.
} 
in own NOT INCORPORATED business, professional practice, or farm" and 7) "SELFEMPLOYED in own INCORPORATED business, professional practice, or farm" (U.S. Census Bureau 1993: E-15).

\section{Results for White Men}

In this section, we document the patterns and analyze the causes of changes in selfemployment rates for white men over the twentieth century. Figure 1 displays black and white male self-employment rates for 1910 and decennially for 1940 through 1990. The white male self-employment rate decreased steadily from its highest point in 1910 (16.0 percent) to its lowest point in 1970 (10.0 percent). ${ }^{11}$ In 1970, the downward trend in the self-employment rate ended and began a climb to 11.4 percent in $1990 .^{12}$ If we limit the sample to full-time, full-year workers, we find a similar trend (see Figure 2). ${ }^{13}$ This similarity rules out the possibility that underemployment or "disguised unemployment" are the driving force behind the major changes in self-employment during the twentieth century (Lebergott 1964; Carter and Sutch 1994).

We now explore potential explanations for the pattern of white self-employment over the twentieth century with an emphasis on hypotheses regarding the recent upturn. These explanations have been proposed in previous studies of self-employment or are suggested by current research on the determinants of self-employment.

\section{TAXES}

A number of authors have argued that taxes will affect the tendency to be self-employed. The usual claim is that high income taxes induce a shift to self-employment in large part because

${ }^{11}$ We defer our discussion of the trend in the black male self-employment rate to Section 5.

${ }^{12}$ Estimates from other data sources confirm this pattern and demonstrate that selfemployment rates do not change substantially on an annual basis (see Aronson 1991 and Steinmetz and Wright 1989).

${ }^{13}$ We define full-time, full-year workers as those who worked at least 35 hours in the week prior to the survey date and at least 40 weeks in the year prior to the survey date. The 1910 estimates, however, include all workers due to data limitations. 
self-employment income can more easily be hidden or sheltered from tax authorities (see Long 1982). Blau (1987), in his study of recent trends in self-employment, attributes most of the increase from 1973 to 1982 to tax changes. In this section, we examine the relationship between trends in tax rates and self-employment since 1910.

Taxes affect the decision between wage/salary work and self-employment by altering the after-tax return to work in the two sectors. Suppose an individual would earn approximately the same in each sector pre-tax, but is able to hide a fraction of that income if the individual chooses self-employment. The return to self-employment is then affected by the tax rate on the last fraction of income that the individual earns, since the individual avoids this tax by being selfemployed. If those deciding to become self-employed are distributed evenly across the income distribution and they expect to hide only a small part of their income, then the average marginal tax rate should capture the tax incentives to be self-employed. Even when these assumptions do not hold precisely, the average marginal tax rate should be a good approximation to the tax advantage of being self-employed.

We focus on the federal income tax here because it is the largest income or payroll tax and because its rates have fluctuated substantially over our period. We use the average marginal tax rate, which is just the average of the marginal rates weighted by the number of taxpayers that pay that rate. In Figure 3, we display the white male self-employment rate and the average marginal tax rate for the period 1910 through 1990. We use the average marginal tax rate calculated by Barro and Sahasakul (1983) through 1980, which we update through 1990. ${ }^{14}$ The average marginal tax rate is under one percent through 1940. It temporarily rises during WWII and the Korean War and then falls after each war, but the rate otherwise has an upward trend through about 1980. After 1980, tax rates fall substantially. This trend does not accord well with hypotheses concerning the relationship between taxes and the trend in the self-employment rate during the twentieth century. Interestingly, the only extended period of time in which selfemployment rates and tax rates move in the same direction is during the 1970s. This period

\footnotetext{
${ }^{14}$ We use and update their returns weighted arithmetic average marginal tax rate. This average is calculated by weighting the individual marginal rates by the number of returns with income such that they pay that marginal rate. Our updated series are available upon request.
} 
happens to be the stretch of time on which Blau (1987) focuses (actually 1973-1982). In the decade following this period, the self-employment rate continues to rise, while the tax rate falls sharply. It is unlikely that the recent changes are due to lagged adjustment because the downturn in rates occurred soon after 1980 and most of the fall in rates had occurred by 1987 . Overall, the relationship between tax rates and self-employment appears to be weak during the twentieth century.

The Social Security payroll tax is the next largest tax on labor, but its incentives are harder to characterize. The self-employment decision depends on the level of the tax as with income taxes, as well as the differential social security tax between wage/salary workers and the selfemployed, the incidence of the tax, and worker valuation of the retirement benefits connected to the tax payments. Focusing first on the level of the tax, Figure 3 also shows the average marginal income tax rate plus the OASDHI rate (employer plus employee) for taxable payroll. The combined rate rises more quickly from 1950 through 1980 and falls less after 1980. While again the longer term tax rate changes to not fit the trends in self-employment, the combined rate does not fall sharply or is even flat during the 1980 s as self-employment continued to rise. ${ }^{15}$ Now turning to the differential treatment of self-employment and wage/salary work under Social Security, there are three main periods to examine. From its inception in 1935 through 1950, Social Security did not levy taxes on the self-employed or make them eligible for retirement benefits. This arrangement probably favored wage/salary work, since the present value of the retirement benefits provided greatly exceeded the present value of the taxes levied. From 19511983, the self-employed were eligible for retirement benefits, but paid a tax rate that was lower than the combined employer and employee tax for wage/salary workers. The differential in the tax rates began at .75 percent and rose to 4.05 by 1983 . Assuming that, on the margin, the incidence of taxes is the same in the two sectors, this differential would favor self-employment, and favored it increasingly over time. Since 1984, Social Security has treated wage/salary

${ }^{15}$ This discussion ignores the marginal return to social security tax payments through higher retirement benefits. Accounting for this return would imply marginal rates lower than the combined rates of Figure 3, but higher than the income tax only rates. It is probably also true that the perceived marginal return to social tax payments has fallen over time, increasing the effective marginal rate. 
workers and the self-employed equivalently. Again, under the assumption that the incidence of the tax is the same on the two types of workers, Social Security would now seem to not alter the relationship between pre- and post-tax comparisons.

\section{SOCIAL SECURITY AND POPULATION AGING}

Quinn (1980) and Fuchs (1982) find that self-employment is much more common among the elderly population. They argue that this is due to the large number of wage/salary workers who switch to self-employment near the end of their careers as a form of partial retirement and the lower likelihood of self-employed workers fully retiring near the end of their careers. These two studies also point out that higher returns to retirement may induce higher rates of selfemployment among the elderly population because the self-employed can partially retire and still receive benefits. In a related study, Blau (1987) uses aggregate U.S. time series data to test whether changes in Social Security benefit levels can explain changes in self-employment from 1948 to 1982 . He finds that the increase in the aggregate self-employment rate from 1973 to 1982 was partly due to increasing real Social Security benefits. His study, however, relies on aggregate self-employment rate data and thus does not estimate the effects of these changes separately for different age groups.

In this section, we examine whether the trend in benefits from the Social Security program since its inception in 1935 has contributed to the trend in self-employment. We also study the more general question of whether changes in self-employment rates among the elderly and/or changes in the percent of the workforce who are elderly have contributed to the trend in the aggregate self-employment rate over the twentieth century.

Over the past 50 years Social Security benefit levels have increased substantially. Evidence of this trend is provided in Figure 4 in which we report the social security replacement rate and the self-employment rates for two age groups. ${ }^{16}$ These two age groups correspond to the

\footnotetext{
${ }^{16}$ The replacement rate is the annual amount of social security benefits payable at the normal retirement age expressed as a percent of earnings in the year prior to the entitlement for the average earner. These rates are taken from U.S. House of Representatives (1994). Blau (1987) uses the average monthly social security benefit in real terms under the OASDI program in his analysis. We prefer our measure because it accounts for changes over time in the level of earnings
} 
different eligibility statuses within the program. Individuals ages 65 and over qualify for full benefits in all years, and individuals ages 62-64 qualify for reduced benefits, but only after 1961 . The replacement rate increased from 26.2 percent in 1940 to 51.1 percent in 1980, then dropped to 43.2 percent in 1990. Overall, the trend in the self-employment rate among workers ages 65 and over appears to follow the trend in social security benefits quite well. ${ }^{17}$ The main exceptions are in the 1960s and 1980s when the changes are in opposite directions. Since 1961, the trend in self-employment among workers ages 62-64 somewhat follows the trend in the replacement rate. Again, the main exception was the increase in self-employment from 1980 to 1990 (which was even larger for this group) and the decline in benefits over the same decade. These estimates suggest that changes in social security benefits may partly account for the trends in selfemployment among the elderly.

We now examine the more general question of whether changes in the elderly selfemployment rate and/or changes in the percent of the workforce who are elderly contributed to the trend in the aggregate self-employment rate. Table 1 reports self-employment rates and employment shares by several age groups for white men. The results indicate that the selfemployment rate among workers ages 55-64 decreased more from 1910 to 1970 and increased more from 1970 to 1990 than did the rate among workers ages 16-54. However, the effects of these changes on the trend in the aggregate rate were small largely because this age group represented only a small part of the total workforce throughout the twentieth century. Another interesting finding is that the share of the workforce who were ages 55 and over increased 6.7 percentage points between 1910 and 1970 and decreased 3.6 percentage points between 1970 and 1990. These changes in the employment share of older workers, who have high self-employment rates, thus worked to diminish both the long-term decline and the recent increase in the aggregate self-employment rate.

of those individuals considering retirement.

${ }^{17}$ We report separate self-employment rates for this age group here, although they are excluded from all other analyses in the paper. 
The net effect of the trend in elderly self-employment rates and the changes in elderly employment shares on the trend in the aggregate self-employment rate was small because those 55-64 were under ten percent of employment in 1990. Furthermore, the self-employment rate among workers ages 16-54 experienced nearly the same 6.0 percentage point decrease from 1910 to 1970 and a slightly larger 1.6 percentage point increase from 1970 to 1990 than occurred in the aggregate self-employment rate. ${ }^{18}$ To conclude, these findings indicate that the long-term decline and the recent upturn in the aggregate white self-employment rate cannot be explained by changes in either the self-employment rate of older workers or the share of the workforce that is older. Furthermore, the trend in social security benefits may have affected the trend in self-employment among the elderly, but it cannot explain the overall trend in the white self-employment rate over the twentieth century.

\section{IMMIGRATION}

Recent studies of self-employment, such as Borjas (1986), Light and Sanchez (1987), Yuengert (1995), and Fairlie and Meyer (1996), find that immigrants have higher self-employment rates than comparable natives. We explore whether changes in immigration patterns or changes in immigrant self-employment rates over the twentieth century contributed to the trend in selfemployment among white men. ${ }^{19}$ In Figure 5, we display white native and immigrant selfemployment rates and the percent of the workforce that is immigrant for all Census years. Remember that our self-employment rates are for white men, thus excluding the large number of Asian immigrants since the passage of the Immigration Reform Act of $1965 .^{20}$ The small immigrant percentage of the white male workforce during most of the twentieth century suggests

${ }^{18}$ The findings for the comparison of trends are the same if we use all workers ages 16 and over to calculate the aggregate self-employment rate.

${ }^{19}$ It is also possible that competition from immigrants could lower the self-employment rate of natives. We look for, but do not find evidence that immigration lowered native black selfemployment in Fairlie and Meyer (1998), but we do find some preliminary evidence that it lowers native nonblack self-employment.

${ }^{20}$ Hispanics are included, however, because we cannot separately identify them for some of the earlier Censuses. 
that immigrants cannot account for a large part of the aggregate trend. Examining the trend in the white native self-employment rate, it is evident that this trend is similar to the trend in the white aggregate rate. In fact, the decrease in the white native rate from 1910 to 1990 was 0.60 percentage points larger than the decrease for the aggregate rate, and the increase from 1970 to 1990 was only 0.08 percentage points smaller. ${ }^{21}$ From 1970 to 1990 , the faster increase in selfemployment among immigrants accounts for only 5.7 percent of the increase in the white selfemployment rate, while there was essentially no change in the percent of the workforce who were immigrants. To conclude, patterns of immigration and immigrant self-employment cannot explain the long-term decline in white self-employment or its recent upturn. Immigration dampened the decline in self-employment from 1910 to 1970 and contributed only slightly to the recent upturn.

\section{EARNINGS}

The standard theoretical model of the decision between self-employment and wage/salary work posits that individuals choose the work sector which provides the greatest expected net income. ${ }^{22}$ Variations of this model also emphasize the roles that an individual's tolerance for risk and the differential levels of risk in the two sectors play in the decision. ${ }^{23}$ Therefore, trends in the distribution of self-employment earnings relative to wage/salary earnings may explain the trend in the self-employment rate during the twentieth century. We examine self-employment and wage/salary earnings for the period 1950 to 1990 because self-employment earnings are not available in the 1910 and 1940 Censuses.

In Table 2, we report various measures of actual and log earnings for white and black fulltime, full-year self-employed and wage/salary workers in 1990 dollars. We report mean earnings,

\footnotetext{
${ }^{21}$ From 1940 to 1970 , however, the large decrease in the immigrant self-employment rate and the declining share of the workforce who were immigrant contributed to the decline in the aggregate self-employment over this period. The decrease in the white native self-employment rate was 0.94 percentage points smaller than the decrease for the white aggregate rate (accounting for 24.5 percent of the decrease in the aggregate rate).

${ }^{22}$ S ee Rees and Shah (1986) and Evans and Jovanovic (1989) for examples.

${ }^{23}$ See Kihlstrom and Laffont (1979).
} 
and the median and mean of log earnings as measures of the central tendency of the return from self-employment and wage/salary work. We report the variance of log earnings as a measure of the dispersion of earnings in the two sectors. Implicit in this section is the assumption that these measures reflect marginal as well as average returns and that the changes over time in the earnings distribution are exogenous. Thus, the tests in this section are joint tests of the model of sectoral choice and these assumptions. ${ }^{24}$

The estimates reported in Table 2 demonstrate that white male workers experienced significant growth in mean and median earnings from 1950 to 1990 in both the self-employment and wage/salary sectors. Relative self-employment earnings, however, followed a different trend. We find that the difference between self-employment and wage/salary mean and median earnings generally increased from 1950 to 1970 and decreased from 1970 to 1990 . Therefore, the selfemployment rate did not increase (decrease) when the financial returns to self-employment relative to wage/salary work increased (decreased). ${ }^{25}$ These opposing trends are surprising in light of the prediction of a positive relationship from the standard theoretical model of the selfemployment decision.

In Table 2, we also report the variance in log earnings for white self-employed and wage/salary workers. In every Census year, the variance of log earnings among the self-employed is substantially higher than among wage/salary workers, suggesting that the returns to selfemployment are riskier. What is important for this analysis is the trend in the relative variance of self-employment earnings from 1950 to 1990. The relative variance of log self-employment earnings decreased from 1950 to 1970 and remained roughly constant through 1990. Therefore, the decline and recent increase in self-employment do not appear to be in response to changes in the relative riskiness of self-employment earnings.

\footnotetext{
${ }^{24}$ The estimates of self-employment income are also likely subject to error because of imprecision in the definition of self-employment income and likely underreporting of income. Our focus, however, on trends in relative income levels lessens the potential for misleading findings if these factors do not change much over time.

${ }^{25}$ Aronson (1991) also finds a commensurate rise in self-employment and drop in the relative returns to self-employment in recent decades.
} 
From 1950 to 1990, the self-employment rate appears to have followed a different trend than that predicted by the standard theoretical model of sectoral choice. However, one may not want to dismiss the model as the reported measures of earnings may not capture the marginal returns in the two sectors and the changes in the returns may not be due to shifts in demand.

\section{INDUSTRY DECOMPOSITIONS}

We now examine patterns of self-employment across industries. In Table 3, we report self-employment rates and employment shares by industry for white male workers in each available Census year. Major changes in both self-employment rates within industries and employment shares across industries occurred during the last 80 years.

To identify the relative importance of trends in these two factors in creating the trend in the aggregate self-employment rate, we perform a decomposition. The aggregate selfemployment rate in each year is equal to the sum of the industry-specific self-employment rates weighted by their employment shares. Therefore, we can represent the change in the aggregate self-employment rate from year $t$ to year $t+s$ as:

$$
\sum_{i=1}^{I} E_{t+s}^{i} S_{t+s}^{i}-\sum_{i=1}^{I} E_{t}^{i} S_{t}^{i}
$$

where $E_{t}^{i}$ is the share of total employment of industry $i$ in year $t, S_{t}^{i}$ is the self-employment rate for industry $\mathrm{i}$ in year $\mathrm{t}$, and $\mathrm{I}$ is the total number of industries. Equation (3.1) can be rewritten as two alternative expressions:

$$
\begin{aligned}
& \sum_{i=1}^{I} E_{t+s}^{i}\left(S_{t+s}^{i}-S_{t}^{i}\right)+\sum_{i=1}^{I}\left(E_{t+s}^{i}-E_{t}^{i}\right) S_{t}^{i}, \text { or } \\
& \sum_{i=1}^{I} E_{t}^{i}\left(S_{t+s}^{i}-S_{t}^{i}\right)+\sum_{i=1}^{I}\left(E_{t+s}^{i}-E_{t}^{i}\right) S_{t+s}^{i} .
\end{aligned}
$$

These two equations represent the decomposition of the change in the aggregate self-employment rate into the part that is due to changes in self-employment rates within industries holding employment shares constant (represented by first summation in each equation) and the part that is 
due to changes in employment shares across industries holding self-employment rates constant (represented by the second summation). ${ }^{26}$

In Table 4, we report estimates of (3.2) and (3.3) for changes in the aggregate selfemployment rate from 1910 to 1940 and decennially from 1940 to 1990 . We also report the decomposition for the entire period of decline (1910-1970) and rise (1970-1990). The Census to Census estimates and the longer time-period estimates essentially provide the same findings for each period. The results indicate that the long-term decline from 1910 to 1970 in the selfemployment rate was due primarily to a decrease in self-employment rates within nearly all industries. The within industry decline, however, was somewhat counterbalanced by a shift in overall employment towards high self-employment industries. The evidence for this explanation is provided by the large contribution (of the same sign as the change in the aggregate selfemployment rate) from changes in self-employment rates within industries from 1910 to 1970 and the smaller contribution (of the opposite sign) from changes in employment shares. The increase in self-employment from 1970 to 1990 was caused by an end to the decline in the self-employment rate within most industries and the continuing shift in overall employment towards high selfemployment industries.

To further explore the causes of the recent increase in the aggregate self-employment rate, we identify the specific industries which contributed to the trend. In particular, we decompose the contribution of each industry to changes in the aggregate self-employment rate into the part that is due to changes in its self-employment rate and the part that is due to changes in its employment share. The contribution of industry $\mathrm{i}, \mathrm{C}$, to the change in the aggregate self-employment rate from 1970 to 1990 can be measured as:

$$
C^{\mathrm{i}}=\mathrm{E}_{90}^{\mathrm{i}}\left(\mathrm{S}_{90}^{\mathrm{i}}-\overline{\mathrm{S}}_{90}\right)-\mathrm{E}_{70}^{\mathrm{i}}\left(\mathrm{S}_{70}^{\mathrm{i}}-\overline{\mathrm{S}}_{90}\right)
$$

\footnotetext{
${ }^{26}$ Two alternative decompositions arise because of the requirement of choosing a base year for the self-employment rates and employment shares.
} 
where $\mathrm{S}_{90}$ is the aggregate self-employment rate in $1990 .{ }^{27}$ This contribution depends on both the size and change in the employment share of this industry and the size and change in the selfemployment rate of this industry relative to the average self-employment rate in 1990. Next we add and subtract $\mathrm{E}_{70}^{\mathrm{i}}\left(\mathrm{S}_{90}^{\mathrm{i}}-\overline{\mathrm{S}}_{90}\right)$ or $\mathrm{E}_{90}^{\mathrm{i}}\left(\mathrm{S}_{70}^{\mathrm{i}}-\overline{\mathrm{S}}_{90}\right)$ to $(3.4)$ to get:

$$
\begin{gathered}
C^{\mathrm{i}}=\left[\mathrm{E}_{70}^{\mathrm{i}}\left(\mathrm{S}_{90}^{\mathrm{i}}-\mathrm{S}_{70}^{\mathrm{i}}\right)\right]+\left[\left(\mathrm{E}_{90}^{\mathrm{i}}-\mathrm{E}_{70}^{\mathrm{i}}\right)\left(\mathrm{S}_{90}^{\mathrm{i}}-\overline{\mathrm{S}}_{90}\right)\right] \text { or } \\
\mathrm{C}^{\mathrm{i}}=\left[\mathrm{E}_{90}^{\mathrm{i}}\left(\mathrm{S}_{90}^{\mathrm{i}}-\mathrm{S}_{70}^{\mathrm{i}}\right)\right]+\left[\left(\mathrm{E}_{90}^{\mathrm{i}}-\mathrm{E}_{70}^{\mathrm{i}}\right)\left(\mathrm{S}_{70}^{\mathrm{i}}-\overline{\mathrm{S}}_{90}\right)\right],
\end{gathered}
$$

respectively. The first term in brackets in each equation represents the contribution from the change in the self-employment rate of industry $i$ to the increase in the aggregate self-employment rate from 1970 to 1990 . The second term represents the contribution from the change in the relative share of total employment experienced by industry i from 1970 to 1990.

In Table 5, we report estimates of (3.4), (3.5), and (3.6). These estimates indicate that the upturn from 1970 to 1990 was partly due to decreases in employment shares in manufacturing and public administration (low self-employment industries) and increases in employment shares in construction, professional services, and business and repair services (high self-employment industries). Increases in the self-employment rate within construction, manufacturing, transportation, and FIRE exerted upward pressure on the aggregate self-employment from 1970 to 1990 . However, the large decrease in the self-employment rate within trade and the smaller decrease within personal services acted to cancel out these effects.

In summary, we find that the long-term decline in self-employment earlier in this century was primarily due to declining rates of self-employment within almost all industries. These patterns are consistent with technological change favoring capital-intensive, large-scale production during this period (see Blau 1987). In comparison, we find that the recent upturn in the aggregate self-employment rate was mainly due to an industrial shift from low to high selfemployment industries. This shift may be due to factors such as changes in consumer demand, increased global competition, and changes in technology. Our findings, however, do not allow us

${ }^{27}$ An alternative method of writing the industry contribution is to replace $S_{90}$ with $S_{70}$ in (3.4). Although not reported, we find that this method provides nearly identical results. 
to disentangle the effects of each of these factors on the trend in the aggregate self-employment rate.

Our results also imply a small role for changes in total factor productivity, as measured by Blau (1987), in explaining the self-employment trends. ${ }^{28}$ Such changes in productivity were one of the two most important explanations Blau (1987) provides for the 1973-82 changes in selfemployment. Blau uses changes in industry employment to calculate the relative total factor productivity in self-employment compared to wage/salary work. Since his measure depends solely on changes in the industry composition of employment, our finding of small effects of such changes between 1910 and 1970 provides an upper bound on the importance of total factor productivity changes of this sort during this earlier period.

\section{Results for Black Men}

We now examine trends in black self-employment during the twentieth century. A few recent studies document and explore causes of the low rate of self-employment among black men. ${ }^{29}$ Using various data sources, these studies generally find that black men are one-third as likely to be self-employed as white men. Low levels of education, low asset levels, smaller probabilities of having self-employed fathers, and consumer discrimination are found to contribute to the lack of self-employment among black men. In addition to these recent studies, a few older studies argue that the absence of black traditions in the field of business enterprise is a major cause of the low level of black self-employment. ${ }^{30}$ We examine whether the long-term trends in several of these or related measures can explain the pattern of black self-employment relative to white self-employment during the twentieth century.

${ }^{28}$ Blau (1987) finds that a measure of technology (total factor productivity weighted by selfemployment and wage/salary industry distributions) explains a large portion of the increase in aggregate self-employment from 1973 to 1982. Changes in his measure of technology, however, may also be due to demand-induced changes in industry structure. He concludes that "the source of the favorable shift in TFP for the self-employed is uncertain."

${ }^{29}$ See Bates (1985, 1989), Borjas and Bronars (1989), Meyer (1990), Fairlie (1996, 1999), and Fairlie and Meyer (1996).

${ }^{30}$ See Du Bois (1899), Myrdal (1944), Drake and Cayton (1945) and Frazier (1949). 
Referring back to Figure 1, we display the black and white self-employment rates and the ratio of the two rates from 1910 to 1990 . During this period, the black self-employment rate generally followed the same time pattern as the white self-employment rate. The main difference was that the decline in black self-employment continued until 1980 and reversed only after that period. The similar trends in the racial self-employment rates resulted in a roughly constant black/white ratio during the past 80 years. These trends in the self-employment rates and the black/white ratio remain essentially unchanged when we include only full-time, full-year workers (see Figure 2). In most years, conditioning on full-time employment increases the white selfemployment rate and decreases the black self-employment rate. These changes, however, are small and thus do not substantially alter the black/white ratio in any of the Census years.

The constancy of the black/white ratio is surprising in light of the substantial gains blacks have made in education, earnings and civil rights during the twentieth century and the numerous government programs created to promote minority business ownership. ${ }^{31}$ We now investigate several possible explanations.

\section{INDUSTRY ANALYSES}

Although black and white overall self-employment rates did not converge during the twentieth century, there may have been convergence or partial convergence in racial selfemployment rates within some industries during this period. In Table 6, we report black selfemployment rates and black/white self-employment rate ratios by industry for 1910 to 1990 . The most striking finding from this table is that black men had substantially lower self-employment rates within all industries and Census years. Transportation and Business and Repair Services are the only industries in which the black self-employment rate was consistently greater than 50 percent of the white rate. This finding indicates that the large racial gap in self-employment throughout the twentieth century was primarily due to low black self-employment rates within industries and not due to blacks being overrepresented in low self-employment rate industries. In

\footnotetext{
${ }^{31}$ See Smith and Welch (1989) for an analysis of black economic progress from 1940 to 1980 and Balkin (1989) for a description of many of the government programs that promote minority self-employment.
} 
fact, the largest positive contribution from racial differences in industry distributions to the black/white gap in aggregate self-employment rates in any Census year is 11.6 percent. ${ }^{32}$ Another interesting finding is that the trends in the black/white ratio for most industries were roughly flat over the twentieth century.

In Table 6, we also report black employment shares by industry. Although a comparison of these estimates to the white employment shares reported in Table 3 reveals some convergence in racial industry distributions, the results indicate that blacks and whites mainly experienced growths and declines in the same industries over the century. ${ }^{33}$ The direct contribution of relative changes over time in racial industry distributions is 0.1 to 13.5 percent of the 1990 black/white self-employment rate gap. ${ }^{34}$ The industrial changes of the U.S. workforce from 1910 to 1990 apparently did not alter the racial gap in the aggregate self-employment rate. Clearly, the similar levels and trends in the black/white self-employment rate ratios across industries were responsible for this finding.

Overall, the findings from this analysis demonstrate that the large gap between the black and the white self-employment rate during the twentieth century was due to the fact that blacks had lower self-employment rates in all industries and not due to the fact that blacks were more

\footnotetext{
${ }^{32}$ The contribution from racial differences in industry distributions in year $\mathrm{t}$ is $\sum_{\mathrm{i}=1}^{\mathrm{I}} \mathrm{S}_{\mathrm{t}}{ }^{\mathrm{W}}\left(\mathrm{E}_{\mathrm{t}}{ }^{\mathrm{W}}-\mathrm{E}_{\mathrm{t}}{ }^{\mathrm{B}}\right)$. The contributions are generally smaller using black self-employment rates as weights.
}

${ }^{33}$ One industry in which blacks experienced faster growth than whites during the twentieth century is Public Administration. This industry is of special interest because a recent study shows that the low rate of self-employment among blacks is partly due to the group's overrepresentation in public sector jobs (see Boyd 1991). We estimate aggregate black and white self-employment rates for each Census year excluding this industry and find that the resulting black/white ratios are very similar to the original ones.

$$
\begin{aligned}
& { }^{34} \text { These contributions are } \sum_{\mathrm{i}=1}^{\mathrm{I}} \mathrm{S}_{1910}^{\mathrm{B}}\left[\left(\mathrm{E}_{1990}^{\mathrm{W}}-\mathrm{E}_{1990}^{\mathrm{B}}\right)-\left(\mathrm{E}_{1910}^{\mathrm{W}}-\mathrm{E}_{1910}^{\mathrm{B}}\right)\right] \text { and } \\
& \sum_{\mathrm{i}=1}^{\mathrm{I}} \mathrm{S}_{1910}^{\mathrm{W}}\left[\left(\mathrm{E}_{1990}^{\mathrm{W}}-\mathrm{E}_{1990}^{\mathrm{B}}\right)-\left(\mathrm{E}_{1910}^{\mathrm{W}}-\mathrm{E}_{1910}^{\mathrm{B}}\right)\right] \text { using black and white self-employment rates, } \\
& \text { respectively. }
\end{aligned}
$$


likely to be located in low self-employment rate industries. Furthermore, the similar trends of blacks and whites in self-employment rates within industries and employment shares across industries contributed to the constancy in the black/white ratio of the aggregate self-employment rate.

\section{EARNINGS}

Since the middle of this century, black men have made substantial improvements in their levels of earnings relative to white men. Evidence of this growth in relative earnings for full-time, full-year workers is provided in Table 2. Both black self-employed and wage/salary workers gained considerable ground on white workers in terms of income levels. What is important in this analysis, however, are comparisons between black and white men in the relative returns to selfemployment. Therefore, we examine patterns of racial differences in the central tendency and dispersion of earnings in self-employment relative to wage/salary work.

The results for relative earnings indicate that the earnings advantage in self-employment, measured as the difference between the median or mean level of log self-employment and wage/salary income, was greater for white men than for black men in almost every year. From 1950 to 1990, however, the earnings advantage in self-employment improved for blacks relative to whites. In contrast, there does not appear to be a clear trend in the relative riskiness of selfemployment for blacks and whites. The relative riskiness of self-employment measured as the difference between the variance of log self-employment and wage/salary earnings was fairly similar for blacks and whites over this century. It fell over time for both groups, with the fall for blacks slightly greater than that for whites.

Again, assuming that the return to a marginal person entering self-employment or wage/salary work is well approximated by the average return, our findings are consistent with lower levels of black self-employment than white self-employment. However, they suggest that the black self-employment rate should have increased relative to the white self-employment rate over the period, given the increased attractiveness of self-employment. Thus, the changes or the lack of changes in the return to self-employment do not appear to be a good explanation for the roughly constant black/white relative self-employment rate over the past 80 years. 


\section{EDUCATION, MIGRATION AND OTHER DEMOGRAPHIC FACTORS}

We now examine the influence of demographic factors on the racial trends in selfemployment. During the twentieth century, the U.S. labor force experienced major geographical, age, and educational shifts. Although the black self-employment rate remained relatively low during the century, these demographic changes may have had large offsetting effects on the difference between white and black self-employment rates. To explore this hypothesis, we employ the decomposition methodology used by Smith and Welch (1989) in their study of trends in racial earnings differences. This decomposition is a dynamic generalization of the familiar method of decomposing intergroup differences in a dependent variable into those due to different observable characteristics across groups and those due to different returns to characteristics across groups (Blinder 1973; Oaxaca 1973).

The first step in computing the decompositions is to estimate a linear probability model of the relationship between self-employment, $\mathrm{S}$, and demographic characteristics, $\mathrm{X}$, using separate cross sections for each race and time period:

$$
S_{t}^{i}=X_{t}^{i} \beta_{t}^{i}+\epsilon_{t}^{i}
$$

where $t$ indexes the Census year $(1910, \ldots, 1990)$ and $\mathrm{i}$ indexes the race $(\mathrm{B}, \mathrm{W}) .{ }^{35}$ Having obtained estimates of the linear probability models by time period and race, the self-employment rate is equal to the inner product of the mean characteristics and the vector of coefficients. We are interested in decomposing changes in the racial self-employment rate gap, defined throughout this analysis as the white rate minus the black rate. Therefore, the change in the racial selfemployment rate gap between two Censuses, $\mathrm{t}=1$ and $\mathrm{t}=2$, is simply

$$
\left(\overline{\mathrm{X}}_{2}^{\mathrm{W}} \beta_{2}^{\mathrm{W}}-\overline{\mathrm{X}}_{2}^{\mathrm{B}} \beta_{2}^{\mathrm{B}}\right)-\left(\overline{\mathrm{X}}_{1}^{\mathrm{W}} \beta_{1}^{\mathrm{W}}-\overline{\mathrm{X}}_{1}^{\mathrm{B}} \beta_{1}^{\mathrm{B}}\right) \text {. }
$$

${ }^{35}$ The linear structure of the decomposition described below makes it substantially more difficult to use a nonlinear method of estimating the self-employment probability, such as a logit or probit model. 
The decomposition of this expression requires first choosing a base year and base race. We use the earlier Census year $(\mathrm{t}=1)$ as the base year and white as the base race. ${ }^{36}$ Using white as the base race, (4.2) can be expressed as:

$\begin{array}{ccc}\text { (i) } & \left.\left[\left(\overline{\mathrm{X}}_{2}^{\mathrm{W}}-\overline{\mathrm{X}}_{2}^{\mathrm{B}}\right)-\left(\overline{\mathrm{X}}_{1}^{\mathrm{W}}-\overline{\mathrm{X}}_{1}^{\mathrm{B}}\right)\right] \beta_{1}^{\mathrm{W}}\right] & + \\ \text { (ii) } & \left(\overline{\mathrm{X}}_{2}^{\mathrm{B}}-\overline{\mathrm{X}}_{1}^{\mathrm{B}}\right)\left(\beta_{1}^{\mathrm{W}}-\beta_{1}^{\mathrm{B}}\right) & + \\ \text { (iii) } & \left(\overline{\mathrm{X}}_{2}^{\mathrm{W}}-\overline{\mathrm{X}}_{2}^{\mathrm{B}}\right)\left(\beta_{2}^{\mathrm{W}}-\beta_{1}^{\mathrm{W}}\right) \\ \text { (iv) } & \overline{\mathrm{X}}_{2}^{\mathrm{B}}\left[\left(\beta_{2}^{\mathrm{W}}-\beta_{2}^{\mathrm{B}}\right)-\left(\beta_{1}^{\mathrm{W}}-\beta_{1}^{\mathrm{B}}\right)\right]\end{array}$

Given the linearity of the decomposition, each of the four components can be further decomposed to capture the contributions of specific variables. We calculate separate contributions from age, family characteristics, education, and region. ${ }^{37}$ To provide an interpretation of each of the components (i-iv) in the decomposition, it is useful to select a specific variable, such as region, in the discussion. The interpretations of the components for the variable, region, are as follows. (i) The "Characteristics Effect" is positive if blacks relative to whites move into low self-employment regions of the country. ${ }^{38}$ This contribution is positive because it increases the racial gap measured as the white minus the black rate. (ii) The "Characteristics-Race Interaction" is positive if blacks relative to whites move into regions which have large racial self-

${ }^{36}$ Smith and Welch (1987) argue for using the white or majority parameter estimates because these estimates more closely resemble market prices of attributes. Donohue and Heckman (1991), however, note that the decomposition results presented in Smith and Welch (1989) are somewhat sensitive to the choice of base race. To address this concern, we also calculate decompositions using black as the base race and compare results.

${ }^{37}$ We also calculate decompositions which include industry controls and compare results. Our primary specification does not include industry controls due to the potential simultaneity of the self-employment and industry decisions.

${ }^{38}$ The terminology for this and the following components of the decompositions follows Fairlie and Sundstrom (1999). 
employment rate gaps. Part of this component may be due to the effect of blacks moving to areas of the country which have high levels of consumer discrimination against self-employed minorities. (iii) The "Coefficients-Race Interaction" is positive if blacks are overrepresented in the regions of the country which have falling self-employment rates over time. Thus, the effect of demand shifts for the goods and services produced by the self-employed are partly captured in this term. (iv) The "Coefficients Effect" is positive if the racial self-employment rate gap is increasing within region. ${ }^{39}$

In Table 7, we report the decomposition of the change in the racial gap for each decade between 1940 and 1990. ${ }^{40}$ The decomposition results for the change between any two Census years (e.g. 1940 to 1990) can be calculated by summing the included decadal decomposition results. In the underlying regressions, we include a constant, age, age squared, and dummy variables for marriage, presence of children, three educational categories (high school graduate, some college, and college graduate), and eight Census divisions. ${ }^{41}$ The difference between the white and black self-employment rates was large in each Census year and experienced only minor changes during this period. Although the changes in the racial gap were small from 1940 to 1990, individual demographic variables may have had large effects on the trend in the gap. We first examine the effect of these variables during the period from 1940 to 1960.

One of the most important demographic changes occurring during the twentieth century was the large exodus of blacks from rural areas in the South to urban areas in the North from 1915 to 1960, known as the Great Black Migration. Using our sample of workers in nonagricultural industries, we find that the percent of black workers living in the South fell from

39 The interpretation of this term for specific subsets of variables is problematic, because it is sensitive to the choice of excluded category. Therefore, we only report the total contribution of this component for all of the variables.

${ }^{40}$ We do not include estimates for 1910 because we do not have measures of some of our important independent variables in this year.

${ }^{41}$ The left-out educational category and Census division are high-school dropouts and New England, respectively. The coefficient estimates from these regressions generally have the anticipated sign in all of the Census years. We find that the probability of being self-employed increases with age, education level, and living in the Pacific division. 
68 percent in 1940 to 52 percent in 1960, whereas the percent of whites living in the South increased slightly over the same period. Our decomposition results indicate that this relative regional shift increased the racial gap during this period somewhat as evidenced by the positive estimates of (i) for 1940 through 1960 that sum to just under .6 percentage points. This small positive direct effect of the Great Black Migration due to the lower self-employment rates in the North that increased the racial gap was more than offset by the fact that blacks were moving into regions with smaller racial gaps in self-employment and that self-employment was increasing in the regions overrepresented by blacks. Evidence of these latter factors, which worked to reduce the racial gap, are provided by the negative estimates of contributions (ii) and (iii) which sum to just over .6 percentage points for this period. All of these effects, however, were small, implying that the major regional shifts that occurred during this period of time had little effect on black selfemployment relative to white self-employment.

During the 1940s and 1950s, racial trends in age, family characteristics and educational distributions also had little effect on changes in the racial self-employment rate gap. These findings are less surprising, however, as the racial difference in mean values of these variables did not change substantially during this period. There is some evidence that the relative trends in selfemployment across educational levels were favorable to less-educated blacks.

We now examine the period from 1960 to 1990. Perhaps the most important demographic change that occurred during this period was the substantial increase in black educational levels relative to those of whites. The percent of the white male workforce who were high school graduates grew from 51.1 percent in 1960 to 85.8 percent in 1990. In comparison, 25.4 percent of employed black men were high school graduates in 1960 increasing to 74.7 percent in 1990. Past research and our regression estimates indicate that the probability of selfemployment increases with education. ${ }^{42}$ Therefore, we expect the relative increase in black educational levels to reduce the racial gap in the self-employment rate (holding other factors

${ }^{42}$ The positive association between education levels and self-employment is partly caused by the higher return to education for self-employed workers than for wage/salary workers. See Evans and Leighton (1989) and Fairlie and Meyer (1996) for evidence. 
constant). Our decomposition estimates indicate, however, that the relative racial trends in educational attainment had only a minor effect on changes in the racial gap.

Examining the other contributions from education, we find that the educational improvements made by blacks placed them in educational categories that had larger racial selfemployment rate gaps. ${ }^{43}$ The negative estimates of (iii) reported in Table 7 indicate that rising self-employment rates among less-educated workers over time reduced the racial gap. Overall, the racial trends in education did not have a large effect on the trend in the racial self-employment rate gap from 1960 to 1990. Furthermore, none of the included variables provided large contributions to changes in the racial gap during this period.

Our results indicate that trends in demographic factors, including the Great Black Migration and the racial convergence in education levels, did not have large effects on the trend in the racial gap in the self-employment rate. ${ }^{44}$ We therefore conclude that the constancy of the racial gap in self-employment was not due to offsetting influences of important racial trends in demographic factors.

\section{PAST SELF-EMPLOYMENT EXPERIENCE}

Past studies such as Du Bois (1899), and later Myrdal (1944), Cayton and Drake (1946) and Frazier (1957) identify the lack of black traditions in business enterprise, in large part due to

${ }^{43}$ An explanation that is consistent with this finding is that more-educated self-employed blacks may have experienced higher levels of consumer discrimination than their less-educated counterparts.

${ }^{44}$ These results are robust to two alternative specifications of the decomposition. First, we estimate (4.3) using blacks as the base race. This decomposition substitutes $\beta_{1}{ }^{\mathrm{B}}$ for $\beta_{1}{ }^{\mathrm{W}}$ in (i), $\left(\mathrm{X}_{2}{ }^{\mathrm{W}}-\mathrm{X}_{1}{ }^{\mathrm{W}}\right)$ for $\left(\mathrm{X}_{2}{ }^{\mathrm{B}}-\mathrm{X}_{1}{ }^{\mathrm{B}}\right)$ in (ii), $\left(\beta_{2}{ }^{\mathrm{B}}-\beta_{1}{ }^{\mathrm{B}}\right)$ for $\left(\beta_{2}{ }^{\mathrm{W}}-\beta_{1}{ }^{\mathrm{W}}\right)$ in (iii), and $\mathrm{X}_{2}{ }^{\mathrm{W}}$ for $\mathrm{X}_{2}{ }^{\mathrm{B}}$ in (iv). There are changes for some of the contribution estimates, however, these changes are small. Furthermore, the changes are generally in the direction of finding weaker effects of our included demographic variables on the trend in the racial self-employment rate gap. Second, we include industry controls in the underlying regressions. We find that the contribution estimates or our demographic variables are not sensitive to their inclusion. In most cases in which there are changes, the estimates became smaller in absolute value. 
slavery, as a major cause of low levels of black business ownership at the time of their analyses. ${ }^{45}$ We take this argument about past experience to mean that lack of past experience in selfemployment per se is the cause of current low rates. We do not take this argument to include other human and physical capital as well as intangibles that are passed intergenerationally. To examine whether this story can explain the lack of convergence of the black rate to the white rate over this century, we begin by examining the microdata evidence on intergenerational links in selfemployment. After having seen that these links are strong, we then do two things. First, we construct a simple model of serial correlation in self-employment rates using evidence from the earlier microdata work. We use this model to approximate the speed with which the effects of the initial low black self-employment would fade, in the absence of other forces reducing black selfemployment. Second, we examine if younger cohorts of blacks are more likely to be selfemployed as would be expected if other forces reducing black self-employment had only recently diminished.

Two recent studies have used nationally representative surveys to examine the extent of the intergenerational correlation in self-employment, Fairlie (1999) and Dunn and Holtz-Eakin (1999). These studies find that an individual who had a self-employed parent is about two to three times as likely to be self-employed as someone who did not have a self-employed parent. ${ }^{46}$

\footnotetext{
${ }^{45}$ See Du Bois (1899, pp. 122-123), Myrdal (1944, pp. 308-309), and Cayton and Drake (1946, p. 437). Frazier (1949, p. 411) provides the clearest statement: "Although no systematic study has been undertaken of the social causes of the failure of the Negro to achieve success as a business man, it appears from what we know of the social and cultural history of the Negro that it is the result largely of the lack of traditions in the field of business enterprise."

${ }^{46}$ Fairlie (1999) uses Panel Study of Income Dynamics (PSID) data to analyze the transition rates into and out of self-employment. He finds that having a self-employed father increases the transition rate into self-employment by 55 percent and decreases the exit rate by 76 percent. Under a constant hazard assumption, the resulting probability of self-employment increases by 72 percent. Dunn and Holtz-Eakin (1999) use National Longitudinal Survey (NLS) data. Depending on the definition of self-employment and the control variables they find that the selfemployment rate of children of self-employed parents is between somewhat less than two and almost three times that of children of parents who are not self-employed. Hout and Rosen (1997) using data from the General Social Survey find that having a self-employed father roughly doubles the probability of self-employment. Another study, Lentz and Laband (1990), examines a sample of "independent businessmen" drawn from the National Federation of Independent Businesses for
} 
This intergenerational relationship is substantial, but whether or not it can explain the constancy of the black/white rate over time requires some modeling.

We use a simple intergenerational model of self-employment to determine how fast low levels of black business ownership in the past should have faded in the absence of intervening factors. The self-employment rate for generation $\mathrm{t}$ is given by the following equation:

$$
\mathrm{S}_{\mathrm{t}}=\mathrm{S}_{\mathrm{t}-1} \mathrm{P}^{\mathrm{S}}+\left(1-\mathrm{S}_{\mathrm{t}-1}\right) \mathrm{P}^{\mathrm{N}}
$$

where $S_{t}$ is the self-employment rate of generation $t, \mathrm{P}^{\mathrm{S}}$ is the probability that the son of a selfemployed man is self-employed, $\mathrm{P}^{\mathrm{N}}$ is the analogous probability for the son of a man who is not self-employed. After assuming values for a few of these parameters, we can determine the predicted black self-employment rate after a given number of generations. We first take the white rate to be in a steady state so that $\mathrm{S}_{\mathrm{t}}=\mathrm{S}_{\mathrm{t}-1}$. We set $\mathrm{S}_{\mathrm{t}}=.11$, which is close to its average over the last four Census years. We further take the initial black rate to be one third that of the white rate and assume that in the absence of other forces depressing black self-employment $\mathrm{P}^{\mathrm{S}}$ and $\mathrm{P}^{\mathrm{N}}$ would be the same for blacks and whites. We take the ratio $\mathrm{P}^{\mathrm{S}} / \mathrm{P}^{\mathrm{N}}$ to be 3 , which is toward the high end of the past estimates. Given the steady-state self-employment rate, we then solve for $\mathrm{P}^{\mathrm{S}}$ and $\mathrm{P}^{\mathrm{N}}$ using (4.4). Under these assumptions, the black rate would be 88 percent of the white rate after one generation and 98 percent of the white rate after two generations. ${ }^{47}$

These calculations show that an initial lack of business experience cannot explain the current low levels of black self-employment without major changes in our assumptions. Substantial deviations from the steady-state assumption and the assumed white self-employment rate are of little quantitative importance for the convergence calculations. The assumed $\mathrm{P}^{\mathrm{S}} / \mathrm{P}^{\mathrm{N}}$ ratio does matter, but values closer to the central tendency of estimates in the literature would lead to faster convergence rates. The assumption that, if changed, could substantially alter the

selected industries. This study finds a much higher rate of intergenerational dependence, but because it examines much larger businesses, we do not think that its results are applicable to the broader group of self-employed that we examine here.

${ }^{47}$ If we assume, instead, that the initial black rate is zero then the black rate achieves 82 percent of the white rate after one generation and 97 percent of the white rate after two generations. 
results is the assumption that business experience is passed from parents to children. It seems likely that parents are the major influence, but other sources of information on acceptable careers and the means to attain them are probably also important (uncles, cousins, neighbors, etc.). However, as long as parents are the major influence, convergence would occur reasonably quickly. It seems very likely to us that the correct interpretation of this discrepancy is that $\mathrm{P}^{\mathrm{S}}$ and $\mathrm{P}^{\mathrm{N}}$ are much lower for blacks than for whites. ${ }^{48}$ In other words, the discrepancy is due to forces which reduce current black self-employment besides the initial conditions of low black selfemployment. The empirical finding of a constant black/white self-employment ratio over the twentieth century implies that there are continuing factors that depress the black self-employment rate. These factors could be discrimination, or they could be skills, capital and intangibles that are passed intergenerationally.

Additional evidence against the lack of traditions in business enterprises argument is provided by the historical experiences of many disadvantaged immigrant groups that came to the U.S. with little prior business experience and created high levels of business ownership after their arrival in the U.S. Perhaps the best example is the experience of Greek immigrants who came to the U.S. from small fishing villages and rural areas, but soon after their arrival created a substantial presence in the restaurant industry in the U.S. ${ }^{49}$ The evidence from the experiences of many immigrant groups in business and the results from our simple intergenerational model of self-employment demonstrate that the lack of traditions in business enterprise among blacks that resulted from slavery cannot explain a substantial part of the current racial gap in selfemployment.

We also examine whether more recent generations of blacks have higher relative selfemployment rates than older generations. In Figure 6, we plot the black/white ratio in the selfemployment rate from 1940 to 1990 for various age cohorts. For example, the oldest cohort displayed was ages 15-24 in 1940. We follow this "synthetic" age cohort over time by examining

\footnotetext{
${ }^{48}$ See Hout and Rosen (1997) for a related analysis which confirms that there are racial differences in $\mathrm{P}^{\mathrm{S}}$ and $\mathrm{P}^{\mathrm{N}}$.

${ }^{49}$ See Aldrich and Waldinger (1990).
} 
the black/white ratio for individuals who were ages 25-34 in 1950, ages 35-44 in 1960, ages 4554 in 1970, and ages 55-64 in 1990. There is no clear evidence of an improvement in relative self-employment rates among younger generations of blacks. Although the youngest cohort has the largest black/white ratio in 1990, the second and third youngest cohorts have low ratios in both 1980 and 1990. The figure also indicates that the black/white ratio does not change substantially as each "synthetic" cohort ages.

\section{ASSETS}

Several previous studies find that asset levels play an important role in determining who enters into or exits from self-employment. ${ }^{50}$ Furthermore, recent studies show that blacks have substantially lower levels of assets than whites and that these differences contribute to the current racial difference in levels of self-employment. ${ }^{51}$ An examination of racial trends in asset levels, therefore, may shed some light on the puzzle of the near constancy of the black/white selfemployment rate ratio over the past 80 years.

In Table 8, we report estimates of mean and median household net worth by race for several years from 1962 to 1991 . The sources of these data are also reported in Table 8. Census data do not include a measure of net worth and only include a measure of interest income for 1980 and 1990. In 1962, which is the earliest year of data available on asset levels by race, the mean value of net worth for blacks was 17.4 percent of the mean value for whites. ${ }^{52}$ The black/white mean net worth ratio rose a small amount by 1967 and rose again by the late 1980s to

${ }^{50}$ See Evans and Jovanovic (1989), Evans and Leighton (1989), Bates (1990), Holtz-Eakin, Joulfaian, and Rosen (1994a,1994b), Dunn and Holtz-Eakin (1999), and Fairlie (1999) and Blanchflower and Oswald (1998).

${ }^{51}$ See Blau and Graham (1992), Oliver and Shapiro (1995) and Menchik and Jianakoplos (1997) for racial differences in assets, and Bates (1990), Meyer (1990) and Fairlie (1999) for evidence on their contributions to racial differences in self-employment, and Blanchflower, Levine and Zimmerman (1998) for evidence on racial disparities in credit availability for small businesses.

${ }^{52}$ Estimates from the 1963 Survey of Financial Characteristics of Consumers (SFCC) use sample weights and are representative of the civilian non-institutional population of the United States. The SFCC includes an oversample of households with income above $\$ 50,000$. See Projector and Weiss (1966) and Avery and Kennickell (1993) for more details on the survey. 
early 1990s. However, even by 1991 black mean net worth was only 25 percent of white net worth. Black median net worth relative to white median net worth was even lower and remained roughly constant over this period. Although blacks have made some gains in mean asset levels relative to whites since the early 1960s, these gains were small and the extremely low levels of black assets throughout this period may have partly restricted a potential increase in the black/white self-employment ratio. We should emphasize that there is a great deal of disagreement in the literature about the importance of low assets in limiting self-employment. There is a significant literature that argues that asset differences are not the crucial explanation and points to the very low levels of investment needed to start enterprises, even ones that become very large. ${ }^{53}$

\section{A Brief Comparison to Numbers from the Current Population Survey (CPS)}

The focus of this paper is the nature and determinants of long-term trends in selfemployment over the twentieth century. The only data available for this purpose are the decennial Censuses. These datasets are also large enough to allow disaggregation of the population in ways that facilitate explaining the changes. In this section we examine annual Current Population Survey (CPS) data since 1966 to examine the trends shown in an alternative data source. This source allows us to examine trends in the last few years and to determine more precisely when declines or increases began. We undertake this analysis, in part, because other research has found a decline in self-employment in recent years. ${ }^{54}$ Other research has emphasized increases in the number of black owned businesses. ${ }^{55}$ We would like to examine if the decennial Censuses provide a misleading picture. The evidence here suggests that the Censuses provide an accurate picture of recent trends in self-employment (also see Appendix A).

\footnotetext{
${ }^{53}$ See Light (1972), Sowell (1981), Meyer (1990) and Bhidé (1998), for example.

${ }^{54}$ See Blanchflower (1998) for example.

${ }^{55}$ See U.S. Small Business Administration (1999) for example.
} 
Table 9 reports non-agricultural self-employment rates for those ages 16-64. We impose minimum hours and weeks worked requirements to make the sample comparable to that from the Census data. We report information from the March CPS Annual Demographic Survey that provides retrospective information on the previous year. Thus, the numbers in the table for a given year were collected the following year. Beginning in 1984, we also report information from the merged outgoing rotation group (ORG) data which provides contemporaneous information on employment during all of the months of the year. We report separate rates for white and black men, as well as the ratio of the black rate to the white rate.

The main disadvantages of the CPS, besides its much shorter time-period, is its smaller size, and that it has been subject to several changes in methodology that seem to coincide with changes in self-employment trends. The changes in CPS methodology are indicated in Table 9 using horizontal lines where there are breaks in the data. These methodological changes make it difficult and problematic to measure changes in self-employment rates around the break points. The break between 1974 and 1975 in the March data is due to the exclusion of incorporated selfemployed among the self-employed prior to 1975. This change appears to raise the white male self-employment rate about 3 percentage points.

In 1994 the CPS was also substantially redesigned. ${ }^{56}$ Since the redesign appears in the March and ORG data in different years, we can examine the effect of the new survey by comparing changes around the break points in the two datasets. These comparisons suggest that the redesign led to a fall in the reported white male self-employment rate of about 1.0 percentage points. ${ }^{57}$ On the other hand, the black male rate seems to have risen, by almost a full percentage point. These results suggest that substantial biases may result from taking the recent CPS

\footnotetext{
${ }^{56}$ For a description of this CPS redesign, see Cohany, Polivka, and Rothgeb (1994), and Polivka and Miller (1998).

${ }^{57}$ In a thorough analysis of the redesign using the "parallel survey", Polivka and Miller (1998) conclude that the redesign raised the self-employment rate of men by about one-half of a percentage point. However the parallel survey seems two have to drawbacks. The sample used for the parallel survey does not appear to have the same characteristics as the regular CPS sample, and interviewer procedures were different. In particular, the interviewers had lower caseloads, and the interviews were longer and were supervised more carefully.
} 
numbers for the white or black self-employment rate at face value, and that recent changes in the black/white ratio may be especially misleading.

Ignoring the changes in rates in the year of methodology changes, the CPS numbers suggest that the white male rate fell slightly through the late 1960s and early 1970s and then rose through 1992 or 1993. This pattern accords well with the timing in the Census data and in other datasets (see Appendix A). Since 1993 or 1994 the white self-employment rate appears to have fallen slightly. The black male rate has followed a similar pattern, though there is less suggestion of a fall in recent years until 1997 when the rate drops substantially. The black/white ratio appears to have been fairly steady at between 0.3 and 0.4 during the years of comparable data. Overall, the changes in recent years do not appear large.

\section{Conclusions}

In our analysis of 1910 and 1940 to 1990 Census microdata, we find that the white male self-employment rate fell from 16.0 percent in 1910 to 10.0 percent in 1970, then rose to 11.4 percent in 1990. We have ruled out a number of possible explanations for the long-term decline and recent upturn in the white self-employment rate. In particular, we find that changes in tax rates, Social Security benefits, the age distribution of the workforce, and immigration do not explain the trends in self-employment. In addition, changes in self-employment earnings relative to wage/salary earnings do not explain the trend in the white self-employment rate from 1950 to 1990. We do find, however, that the long-term decline was mainly due to declining selfemployment rates within nearly all industries, and the recent upturn was mainly due to a shift of overall employment to high self-employment industries. These findings are consistent with technological change favoring capital-intensive, large-scale production during the period from 1910 to 1970 , and changes in consumer demand, increased global competition and changes in technology favorable to self-employment during the period from 1970 to 1990.

We find that the self-employment rate of black men relative to white men has remained roughly constant from 1910 to 1990. Substantially lower black self-employment rates were found in all industries and Census years. The relative earnings of blacks in self-employment rose more than relative earnings for whites in recent decades, making the near constancy of the relative self- 
employment rates even more surprising. Major demographic changes occurring during the twentieth century, such as the Great Black Migration and the racial convergence in educational attainment, did not have large effects on the racial self-employment rate gap. We show using a simple intergenerational model of self-employment that, if not for continuing factors reducing black self-employment, racial convergence in self-employment rates should occur in only a couple of generations. We also do not find higher relative self-employment rates among more recent cohorts of black men than among older cohorts.

We show that blacks have gained little ground on whites in terms of asset levels in the past three decades. These small gains and the extremely low levels of black assets throughout this period may have partly restricted a potential increase in the black/white self-employment ratio. However, more analysis of this issue is needed. The lack of data on racial differences in net worth prior to 1962 and the comparability of data since then greatly limit our ability to compare long-run trends in racial differences in asset levels and self-employment. With available data, we also cannot carefully examine the role that other factors, such as consumer and lending discrimination, and risk aversion, have played in causing the absence of convergence of the black and white selfemployment rates during this century. 


\section{References}

Aldrich, Howard E., and Roger Waldinger. 1990. "Ethnicity and Entrepreneurship," Annual Review of Sociology, 16, pp. 111-135.

Aronson, Robert L. (1991): Self-Employment: A Labor Market Perspective, Ithaca: ILR Press.

Avery, Robert B., and Arthur B. Kennickell. 1993. "U.S. Household Wealth: Changes from 1983 to 1986," Research on Economic Inequality: Studies in the Distribution of Household Wealth, 4, p. 27-68.

Barro, Robert J., and Chaipat Sahasakul (1983): "Measuring the Average Marginal Tax Rate from the Individual Income Tax," Journal of Business, 56, pp. 419-452.

Bates, Timothy (1987): "Self-Employed Minorities: Traits and Trends," Social Science Quarterly, 68 , pp. 539-551.

Bates, Timothy (1989): "The Changing Nature of Minority Business: A Comparative Analysis of Asian, Nonminority, and Black-Owned Businesses," The Review of Black Political Economy, pp. 25-42.

Bates, Timothy (1990): "Entrepreneur Human Capital Inputs and Small Business Longevity," The Review of Economics and Statistics, 4, pp. 551-559.

Becker, Eugene H. (1984): "Self-Employed Workers: An Update to 1983," Monthly Labor Review, 107, pp. 14-18.

Benus, J. M., Johnson, T. R, Wood, M., Grover, N., \& Shen, T. (1995): Self-employment programs: A new reemployment strategy: Final report on the UI Self-Employment Demonstration (Unemployment Insurance Occasional Paper 95-4). Washington, DC: U.S. Department of Labor, Employment and Training Administration, Unemployment Insurance Service.

Bhidé, Amar (1998): "the origin and Evolution of New Businesses: Part I," Working Paper, Division of Research, Harvard Business School, February 1998.

Birch, David (1979): The Job Creation Process, Cambridge, MA: Center for the Study of Neighborhood and Regional Change, Cambridge: MIT Press.

Blanchflower, David G. 1998. "Self-employment in OECD Countries." Dartmouth College, Working Paper. 
Blanchflower, David G and Andrew J. Oswald. 1998. "What Makes an Entrepreneur?" Journal of Labor Economics 16, 26-60.

Blanchflower, David G., Phillip B. Levine, and David J. Zimmerman (1998). "Discrimination in the Small Business Credit Market," National Bureau of Economic Research Working Paper \#6840.

Blau, David M. (1987): "A Time-Series Analysis of Self-Employment in the United States," Journal of Political Economy, 95, pp. 445-467.

Blau, Francine, and David Graham (1990): "Black-White Differences in Wealth and Asset Composition," Quarterly Journal of Economics, pp. 321-339.

Borjas, George (1986): "The Self-Employment Experience of Immigrants," Journal of Human Resources, 21, pp. 487-506.

Borjas, George, and Stephen Bronars (1989): "Consumer Discrimination and Self-Employment," Journal of Political Economy, 97, pp. 581-605.

Bregger, John E. (1963): "Self-Employed in the United States, 1948-1962," Monthly Labor Review, 86 pp. 37-43.

Brown, Charles, James Hamilton, and James Medoff (1990): Employers Large and Small, Cambridge: Harvard University Press.

Blinder, Alan S., "Wage Discrimination: Reduced Form and Structural Variables." Journal of Human Resources, 8 (1973), pp. 436-455.

Boyd, Robert L. (1991): "A Contextual Analysis of Black Self-Employment in Large Metropolitan Areas, 1910-1980," Social Forces, 70, 2, pp. 409-429.

Carter, Susan B. and Richard Sutch (1994): "Self-Employment in the Age of Big Business: Toward an Appreciation of an American Labor Market Institution," Working Papers on the History of Retirement, History of Retirement Project, University of California.

Cayton, Horace R. and St. Clair Drake. 1946. Black Metropolis. London: Jonathan Cape.

Cohany, Sharon, Anne Polivka, and Jennifer Rothgeb (1994): "Revisions in the Current Population Survey Effective January 1994.” Employment and Earnings, 41(2), February 1994, 13-37. 
Donohue, John H., and James Heckman, "Continuous versus Episodic Change: The Impact of Civil Rights Policy on the Economic Status of Blacks," Journal of Economic Literature, 29 (December 1991), pp. 1603-1643.

Du Bois, W.E.B. 1899. The Philadelphia Negro, Philadelphia: University of Pennsylvania.

Dunn, Thomas A. and Douglas J. Holtz-Eakin. 1999. "Financial Capital, Human Capital, and the Transition to Self-Employment: Evidence from Intergenerational Links," Journal of Labor Economics forthcoming.

Evans, David, and Linda Leighton (1989): "Some Empirical Aspects of Entrepreneurship," American Economic Review, 79, pp. 519-535.

Evans, David, and Boyan Jovanovic (1989): "An Estimated Model of Entrepreneurial Choice Under Liquidity Constraints," Journal of Political Economy, 97, pp. 808-827.

Fain, T. Scott (1980): "Self-Employed Americans: Their Number Has Increased," Monthly Labor Review, 103 pp. 3-8.

Fairlie, Robert W. 1996. Ethnic and Racial Entrepreneurship: A Study of Historical and Contemporary Differences. New York: Garland Publishing.

Fairlie, Robert W. 1999. "The Absence of the African-American Owned Business: An Analysis of the Dynamics of Self-Employment." Journal of Labor Economics, 17(1): 80-108.

Fairlie, Robert W., and Bruce D. Meyer (1996): "Ethnic and Racial Self-Employment Differences and Possible Explanations," Journal of Human Resources, 31, Fall 1996, pp. 757-793.

Fairlie, Robert W. and Bruce D. Meyer. 1998. "Does Immigration Hurt African-American SelfEmployment?," (with Robert W. Fairlie), in Help or Hindrance? The Economic Implications of Immigration for African Americans, edited by Daniel S. Hamermesh and Frank D. Bean, Russell Sage Foundation, 185-221.

Fairlie, Robert W. and William A. Sundstrom (1999) "The Emergence, Persistence, and Recent Widening of the Racial Unemployment Gap," Industrial and Labor Relations Review, 52(2): 252-270.

Frazier, E. Franklin (1957): The Negro in the United States, 2nd Edition, New York: McMillan.

Fuchs, Victor R. (1982): "Self-Employment and Labor Force Participation of Older Males," Journal of Human Resources, 17, pp. 339-357. 
Glazer, Nathan and Daniel P. Moynihan (1970): Beyond the Melting Pot, 2nd Edition, Cambridge: MIT Press.

Holtz-Eakin, Douglas, David Joulfaian, and Harvey Rosen (1994a): "Entrepreneurial Decisions and Liquidity Constraints," Rand Journal of Economics, 23, 2, pp. 334-347.

Holtz-Eakin, Douglas, David Joulfaian, and Harvey Rosen (1994b): "Sticking It Out: Entrepreneurial Survival and Liquidity Constraints," Journal of Political Economy, pp. 5375.

Hout, Michael, and Harvey Rosen (1997): "Self-Employment, Family Background, and Race," Working Paper, September 1997.

Jovanovic, Boyan (1982): "Selection and the Evolution of Industry," Econometrica, 50, pp. 649670.

Kihlstrom, Richard, and Jean-Jacques Laffont (1979): "A General Equilibrium Entrepreneurial Theory of Firm Formation Based on Risk Aversion," Journal of Political Economy, 87, pp. 719-748.

Lazear, Edward P., and Robert L. Moore (1984): "Incentives, Productivity, and Labor Contracts," Quarterly Journal of Economics, (May 1984), 275-296.

Lebergott, Stanley (1964): Manpower in Economic Growth: The American Record Since 1800, New York: McGraw-Hill.

Lentz, Bernard, and David Laband (1990): "Entrepreneurial Success and Occupational Inheritance among Proprietors," Canadian Journal of Economics, 23, No. 3, pp. 563-579.

Light, Ivan (1972): Ethnic Enterprise in America, Berkeley: University of California Press.

Light, Ivan (1979): "Disadvantaged Minorities in Self Employment." International Journal of Comparative Sociology 20(1-2): 31-45.

Light, Ivan and Angel A. Sanchez (1987): "Immigrant Entrepreneurs in 272 SMSAs." Sociological Perspectives 30: 373-99.

Long, James E. (1982): "The Income Tax and Self-Employment," National Tax Journal, 35, 1, pp. 31-42.

Lucas, Robert E. (1978): "On the Size Distribution of Firms," The Bell Journal of Economics, 9, pp. 508-523. 
Menchik, Paul L. and Nancy A. Jianakoplos. 1997. "Black-White Wealth Inequality: Is Inheritance the Reason?," Economic Inquiry, 35(2), p. 428-442.

Meyer, Bruce (1990): "Why Are There So Few Black Entrepreneurs?," National Bureau of Economic Research, Working Paper No. 3537.

Mills, C. Wright (1951): White Collar, New York: Oxford University Press.

Moore, Robert L. (1983): Self-Employment and the Incidence of the Payroll Tax," National Tax Journal, 36, 4, pp. 491-501.

Moore, Robert L. (1983): "Employer Discrimination: Evidence form Self-employed Workers," Review of Economics and Statistics, 65 (August 1983): 496-501.

Myrdal, Gunnar. 1944. An American Dilemma, New York: Harper and Brothers.

Oaxaca, Ronald, "Male-Female Wage Differentials in Urban Labor Markets," International Economic Review, 14 (October 1973), pp. 693-709.

Oliver, Melvin L. and Thomas M. Shapiro Black Wealth/White Wealth: A New Perspective on Racial Inequality, New York: Routledge.

Phillips, Joseph D. (1962): The Self-Employed in the United States, Urbana: University of Illinois.

Polivka, Anne E. and Stephen M. Miller (1998): "The CPS After the Redesign: Refocusing the Economic Lens.” In Labor Statistics Measurement Issues. ed. John Haltiwanger, Marilyn E. Manser, and Robert Topel, 249-286. University of Chicago Press.

Projector, Dorothy S., and Gertrude S. Weiss (1966): Survey of Financial Characteristics of Consumers. Board of Governors of the Federal Reserve System.

Quinn, Joseph (1980): "Labor Force Participation of Older Self-Employed Workers," $\underline{\text { Social }}$ Security Bulletin, 43, pp. 17-28.

Raheim, Salome (1997): "Problems and prospects of self-employment as an economic independence option for welfare recipients," Social Work, 42, 1, pp. 44-53.

Ray, Robert N. (1975): "Self-Employed Americans in 1973," Monthly Labor Review, 98, pp. 4954.

Reardon, Elaine. 1992. "Self-Employment Programs for Low-Income Men: Spitting into the Wind?," University of Chicago, Working Paper. 
Rees, H., and A. Shah (1986): "An Empirical Analysis of Self-Employment in the U.K.," Journal of Applied Econometrics, 1, pp. 95-108.

Rettenmaier, Andrew J. (1996): "A Little or a Lot: Self-Employment and Hours of Work," Paper presented at the Society of Labor Economists Annual Meeting, Chicago 1996.

Smith, James P. and Finis R. Welch. 1989. "Black Economic Progress After Myrdal," Journal of Economic Literature, XXVII, pp. 519-564.

Sowell, Thomas. 1981. Markets and Minorities. New York: Basic Books.

Steinmetz, George and Erik Olin Wright (1989): "The Fall and Rise of the Petty Bourgeoisie: Changing Patterns of Self-Employment in the Postwar United States," American Journal of Sociology, 94, pp. 973-1018.

U.S. Bureau of the Census. 1992. Characteristics of Business Owners. Washington: USGPO.

U.S. Bureau of the Census. 1993. Census of Population and Housing, 1990: Public Use Microdata Sample U.S. Technical Documentation. Washington: USGPO.

U.S. Department of Commerce. 1994. Household Wealth and Asset Ownership: 1991. Current Population Reports, Household Economic Studies, P70-34. Washington: USGPO.

U.S. Department of Labor. 1992. Self-Employment Programs for Unemployed Workers. Unemployment Insurance Occasional Paper 92-2. Washington: USGPO.

U.S. House of Representatives. 1994. Overview of Entitlement Programs: 1994 Green Book. Committee on Ways and Means. Washington: USGPO.

U.S. Small Business Administration. 1999. Minorities in Business. Office of Advocacy. Washington, DC.

Weber, Max (1958): The Protestant Ethic and the Spirit of Capitalism, New York: Scribner.

Wolpin, Kenneth I. (1977): "Education and Screening," American Economic Review 67, 949958.

Yuengert, Andrew M. 1995. "Testing Hypotheses of Immigrant Self-Employment." Journal of Human Resources 30(1):194-204. 
</ref_section> 
Appendix A

\section{Comparison of Estimates of Black and White Self-Employment Rates}

We can compare our Decennial Census results to those from other data sets where sample frames and time periods allow an overlap. Our estimates for white men display a similar trend in self-employment rates to estimates from other sources of total self-employment rates over the second half of the century, in particular 1970 is often the year of lowest self-employment. Using Social Security data, Aronson (1991, p. 3) reports that the total self-employment rate declined from 1955 to 1970 and increased from 1970 to 1988 . Becker (1984, p. 15) uses data from the Current Population Survey (CPS) and finds that the proportion of nonagricultural workers who were self-employed decreased from 1948 to 1970 , then increased from 1970 to $1982 .{ }^{58}$

We also can compare our estimates to those from other data sets that include black men. Estimates from the PSID indicate that black and white male self-employment rates did not change substantially from the early 1970 's to the late 1980 's. ${ }^{59}$ Furthermore, black/white self-employment rate ratios were equal to approximately one-third over this entire period. Reardon (1992) reports estimates from the CPS which indicate that the black male self-employment rate increased from an average of 4.1 percent between 1976 and 1981 to an average of 4.5 percent between 1985 and 1989. The white male self-employment rate increased from an average of 12.6 percent to 13.2 percent. These changes imply that the black/white self-employment rate ratio increased from 0.325 to 0.341 over this period. In addition, Devine (1992) reports estimates from the CPS indicating that from 1975 to 1990 the black self-employment rate increased only slightly relative to the white self-employment rate. Estimates from the PSID and CPS concur with our estimates from Census microdata in reporting that the black self-employment rate did not change substantially relative to the white self-employment rate in recent years.

Estimates from the SMOBE, however, show a different trend for black self-employment rates over the last 20 years than do estimates from the Census. According to the SMOBE, the number of black-owned businesses increased from 176,733 in 1969 to 411,600 in $1987 .{ }^{60}$ In comparison, published Census estimates report that the number of black-owned businesses increased from 208,606 in 1970 to 321,516 in 1990. Clearly, the Census estimates show a much smaller increase over roughly the same period. Most of the discrepancy between the two estimates of growth rates appears to have occurred between 1977 and 1987.

The number of businesses estimated in the SMOBE is different from Census estimates because the methods used to create the samples are different. The SMOBE is drawn from IRS records which identifies all individuals who file an IRS form 1040 Schedule C (individual

${ }^{58} \mathrm{Blau}(1987, \mathrm{p} .447)$ reports a similar trend for the male self-employment rate.

${ }^{59}$ These estimates are taken from background research for Fairlie (1994).

${ }^{60}$ Estimates from the SMOBE do not include incorporated businesses other than Scorporations. Therefore, we remove S-corporations from the SMOBE counts and the incorporated self-employed from Census counts to allow direct comparisons between estimates from these two sources. 
proprietorship or self-employed person), 1065 (partnership), or 1120S (subchapter S

corporation). Therefore, the SMOBE includes all individuals who report receiving selfemployment income. This includes a number of individuals whose primary job activity is wage/salary work, but who also own a side business. This is different from the Census which identifies the self-employed as those workers who report their primary job activity as being selfemployment. The Census provides estimates of the number of individuals whose primary job activity is self-employment instead of wage/salary work. The differences in black selfemployment trends between SMOBE and other sources has not been resolved. 


\section{Appendix B}

Description of Data

\section{A. Sampling Procedure}

This study uses individual data from seven decennial Censuses of Population: 1910, and 1940 through 1990. We create random samples from the following Census Public Use Microdata files. For 1910, we select our sample from a nationally representative 1/250 sample which was originally drawn from microfilmed records of the original Census enumeration forms. For 1940 and 1950, we use the 1/100 samples which were encoded from microfilmed copies of handwritten enumeration schedules from the original Censuses. Many of the variables needed for this analysis are only available for "sample line" individuals in the 1950 Census. These individuals represent approximately $1 / 4$ of the total sample. Estimates of black and white self-employment rates from this sample are nearly identical to estimates from the full sample. For 1960 and 1970, we draw from the 1/100 samples, and for 1980 and 1990 we draw from the 5\% samples. The resulting sample sizes are:

$\begin{array}{lll}\text { Census Year } & \frac{\text { Black Men }}{5057} & \text { White Men } \\ 1910 & 14715 & 39733 \\ 1940 & 6934 & 39529 \\ 1950 & 27054 & 39211 \\ 1960 & 35627 & 39726 \\ 1970 & 39646 & 44394 \\ 1980 & 37190 & 39952 \\ 1990 & & 39471\end{array}$

\section{B. Self-Employment Status}

We distinguish between self-employment and wage/salary work based on the individual's response to the class of worker question found on each of the included Censuses. The possible responses to this question changed only slightly across Censuses, mostly affecting the possibility of disaggregating the self-employed into subcategories in certain years. In the 1910 and 1940 Censuses, the self-employed are defined as those workers who respond as being an employer or working on own account to the class of worker question, and wage/salary workers are those who respond as being a wage or salary worker or an unpaid family worker. The 1910 Census does not include "unpaid family workers" as a possible separate response. In the 1950 and 1960 Censuses, self-employment is defined as those responding as self-employed with own business. In the 1970, 1980 and 1990 Censuses, the class of worker question includes separate responses for selfemployed with own not incorporated business and self-employed with own incorporated business. For these three years both of these responses are coded as self-employment.

\section{Racial Status}

We are interested in comparing African-American self-employment patterns to those of whites. Therefore, we only include individuals who indicate that their race is black or white. In the 1940 through 1970 Censuses the response to the race question is actually "Negro" instead of 
"black." We do not separately identify or exclude Hispanics from this study because they are not identified in the earlier Censuses. The 1910 Census allows individuals to report their race as being Mulatto in addition to being black. Of all sample members in the 1910 Census, 2.3 percent and 8.5 percent report a Mulatto and black race, respectively. Census enumerators were instructed to report a respondent's race as being "black" for all individuals who were "evidently full-blooded Negroes," and "Mulatto" for all individuals having "some proportion or perceptible trace of Negro blood". For the 1910 sample, we include both responses in our definition of black.

\section{Income Measures}

Measures of self-employment and wage/salary income changed slightly over the Censuses. To obtain consistency in this measure across each Census year, we use several procedures. First, we do not include data from the 1910 and 1940 Censuses because data on self-employment income are not included in these years. Second, the 1950 and 1960 Censuses do not include separate measures of non-farm and farm net business income. Therefore, we combine non-farm and farm self-employment income for all years. Third, the 1950, 1960 and 1970 Censuses report only categorical income data. For these years, we assign the midpoint of each interval. Fourth, only the presence and not the actual amount of negative self-employment income is recorded on the 1950 Census. Therefore, we recode negative self-employment income levels as being equal to zero for all years. Fifth, the top codes for income levels (in 1990 dollars) are 56,100 in 1950, 109,000 in 1960, 161,500 in 1970, and 118,500 in 1980. The 1990 top codes are more complicated and depend on the state (see the 1990 PUMS Technical Documentation). We assign the value of the top code for these individuals. Finally, for each individual income is defined as the sum of his/her self-employment and wage/salary incomes. Therefore, an individual's income type is defined in our analysis solely by his/her work status.

\section{Other Variables}

Other variables important to this analysis, such as age, education, region, hours worked last week, and weeks worked last year, remained fairly consistent over each Census. Measures of education, hours worked, and weeks worked are not available in the 1910 Census. Detailed industry codes changed from Census to Census, however, the broad groupings used in this analysis are consistent across Census years. 
Table 1

White Self-Employment Rates and Employment Shares by Age Group

\begin{tabular}{|c|c|c|c|c|c|c|c|}
\hline Age Group & 1910 & 1940 & 1950 & 1960 & 1970 & 1980 & 1990 \\
\hline \multicolumn{8}{|c|}{ Self-Employment Rates } \\
\hline Ages $16-24$ & $4.6 \%$ & $4.6 \%$ & $4.0 \%$ & $2.7 \%$ & $2.3 \%$ & $2.9 \%$ & $2.8 \%$ \\
\hline Ages 25-34 & $14.4 \%$ & $10.2 \%$ & $9.8 \%$ & $7.5 \%$ & $7.1 \%$ & $9.5 \%$ & $8.9 \%$ \\
\hline Ages $35-44$ & $21.8 \%$ & $15.7 \%$ & $15.9 \%$ & $12.5 \%$ & $12.4 \%$ & $14.0 \%$ & $14.3 \%$ \\
\hline Ages $45-54$ & $26.5 \%$ & $19.8 \%$ & $18.2 \%$ & $14.8 \%$ & $13.0 \%$ & $15.3 \%$ & $14.9 \%$ \\
\hline Ages $55-61$ & $29.0 \%$ & $22.8 \%$ & $17.2 \%$ & $17.2 \%$ & $15.2 \%$ & $14.3 \%$ & $16.7 \%$ \\
\hline Ages $62-64$ & $30.6 \%$ & $25.9 \%$ & $17.8 \%$ & $17.6 \%$ & $16.5 \%$ & $17.8 \%$ & $21.4 \%$ \\
\hline Ages $16-54$ & $15.1 \%$ & $12.8 \%$ & $12.5 \%$ & $10.2 \%$ & $9.1 \%$ & $10.1 \%$ & $10.7 \%$ \\
\hline Ages 55-64 & $29.4 \%$ & $23.6 \%$ & $17.4 \%$ & $17.3 \%$ & $15.6 \%$ & $15.1 \%$ & $17.8 \%$ \\
\hline \multicolumn{8}{|c|}{ Employment Shares } \\
\hline Ages 16-24 & $27.7 \div$ & $16.7 \%$ & $14.8 \%$ & $13.0 \%$ & $16.7 \%$ & $21.0 \%$ & $15.2 \%$ \\
\hline Ages 25-34 & $29.4 \%$ & $28.8 \%$ & $28.2 \%$ & $25.3 \%$ & $24.0 \%$ & $29.3 \%$ & $30.0 \%$ \\
\hline Ages $35-44$ & $22.3 \%$ & $25.5 \%$ & $25.4 \%$ & $27.0 \%$ & $23.2 \%$ & $20.8 \%$ & $26.9 \%$ \\
\hline Ages $45-54$ & $14.1 \%$ & $19.6 \%$ & $19.6 \%$ & $22.0 \%$ & $22.8 \%$ & $17.7 \%$ & $18.3 \%$ \\
\hline Ages $55-61$ & $4.8 \%$ & $7.1 \%$ & $8.8 \%$ & $9.2 \%$ & $9.9 \%$ & $8.8 \%$ & $7.3 \%$ \\
\hline Ages $62-64$ & $1.7 \%$ & $2.4 \%$ & $3.2 \%$ & $3.4 \%$ & $3.3 \%$ & $2.4 \%$ & $2.2 \%$ \\
\hline Ages 16-54 & $93.5 \%$ & $90.5 \%$ & $88.0 \%$ & $87.4 \%$ & $86.8 \%$ & $88.7 \%$ & $90.4 \%$ \\
\hline Ages $55-64$ & $6.5 \%$ & $9.5 \%$ & $12.0 \%$ & $12.6 \%$ & $13.2 \%$ & $11.3 \%$ & $9.6 \%$ \\
\hline Sample Size & 39733 & 39529 & 39211 & 39726 & 44394 & 39952 & 39471 \\
\hline \multicolumn{8}{|c|}{$\begin{array}{l}\text { Notes: (1) The sample consists of male nonagricultural workers (ages 16-64) } \\
\text { who worked at least } 15 \text { hours in the week prior to the survey date and at least } \\
14 \text { weeks in the year prior to survey date. We do not impose hours and weeks } \\
\text { worked restrictions in } 1910 \text { due to data limitations. (2) The self-employment } \\
\text { rate is the percentage of all those working who are self-employed. } \\
\text { (3) Estimates for } 1990 \text { are calculated using weights provided by the Census. }\end{array}$} \\
\hline
\end{tabular}


Table 3

White Self-Employment Rates and Employment Shares by Industry

\begin{tabular}{|c|c|c|c|c|c|c|c|}
\hline Industry & 1910 & 1940 & 1950 & 1960 & 1970 & 1980 & 1990 \\
\hline \multicolumn{8}{|c|}{ Self-Employment Rates } \\
\hline Mining & $3.8 \%$ & $4.8 \%$ & $3.8 \%$ & $3.1 \%$ & $5.3 \%$ & $4.5 \%$ & $5.0 \%$ \\
\hline Construction & $20.8 \%$ & $21.2 \%$ & $19.2 \%$ & $19.9 \%$ & $17.2 \%$ & $21.3 \%$ & $22.0 \%$ \\
\hline Manufacturing & $5.5 \%$ & $3.2 \%$ & $3.5 \%$ & $2.4 \%$ & $2.6 \%$ & $3.4 \%$ & $4.3 \%$ \\
\hline Transportation & $2.9 \%$ & $6.4 \%$ & $5.2 \%$ & $4.6 \%$ & $4.2 \%$ & $4.7 \%$ & $5.8 \%$ \\
\hline Trade & $37.7 \%$ & $27.1 \%$ & $26.7 \%$ & $22.6 \%$ & $16.8 \%$ & $15.3 \%$ & $11.6 \%$ \\
\hline FIRE & $26.9 \%$ & $14.8 \%$ & $16.1 \%$ & $13.8 \%$ & $12.6 \%$ & $14.3 \%$ & $18.5 \%$ \\
\hline Bus. and Repair & $39.2 \%$ & $30.9 \%$ & $30.0 \%$ & $28.9 \%$ & $23.8 \%$ & $25.5 \%$ & $21.9 \%$ \\
\hline Personal Serv. & $35.6 \%$ & $29.6 \%$ & $29.5 \%$ & $34.8 \%$ & $32.3 \%$ & $30.1 \%$ & $23.6 \%$ \\
\hline Ent. and Rec. & $26.1 \%$ & $16.9 \%$ & $14.4 \%$ & $18.5 \%$ & $20.7 \%$ & $19.9 \%$ & $13.1 \%$ \\
\hline Professional & $42.3 \%$ & $27.8 \%$ & $20.5 \%$ & $19.4 \%$ & $15.3 \%$ & $14.8 \%$ & $14.5 \%$ \\
\hline Public Admin. & $0.5 \%$ & $0.0 \%$ & $0.0 \%$ & $0.0 \%$ & $0.0 \%$ & $0.0 \%$ & $0.0 \%$ \\
\hline Total & $16.7 \%$ & $13.9 \%$ & $13.1 \%$ & $11.4 \%$ & $10.0 \%$ & $11.0 \%$ & $11.4 \%$ \\
\hline \multicolumn{8}{|l|}{ Employment Shares } \\
\hline Mining & $6.0 \%$ & $3.3 \%$ & $2.9 \%$ & $1.7 \%$ & $1.3 \%$ & $1.9 \%$ & $1.1 \%$ \\
\hline Construction & $11.1 \%$ & $7.4 \%$ & $9.3 \%$ & $9.5 \%$ & $9.3 \%$ & $9.7 \%$ & $11.2 \%$ \\
\hline Manufacturing & $32.8 \%$ & $33.8 \%$ & $33.4 \%$ & $36.3 \%$ & $32.9 \%$ & $28.7 \%$ & $23.7 \%$ \\
\hline Transportation & $16.4 \%$ & $11.3 \%$ & $11.2 \%$ & $10.0 \%$ & $9.1 \%$ & $9.9 \%$ & $9.8 \%$ \\
\hline Trade & $18.6 \%$ & $21.8 \%$ & $21.3 \%$ & $18.8 \%$ & $20.0 \%$ & $19.7 \%$ & $20.6 \%$ \\
\hline FIRE & $2.8 \%$ & $4.0 \%$ & $3.3 \%$ & $3.9 \%$ & $4.5 \%$ & $4.8 \%$ & $5.7 \%$ \\
\hline Bus. and Repair & $1.8 \%$ & $3.1 \%$ & $3.8 \%$ & $3.4 \%$ & $3.6 \%$ & $5.1 \%$ & $5.9 \%$ \\
\hline Personal Serv. & $3.7 \%$ & $3.7 \%$ & $2.7 \%$ & $2.2 \%$ & $1.8 \%$ & $1.4 \%$ & $1.5 \%$ \\
\hline Ent. and Rec. & $0.8 \%$ & $1.2 \%$ & $1.0 \%$ & $0.8 \%$ & $0.7 \%$ & $0.9 \%$ & $1.5 \%$ \\
\hline Professional & $4.5 \%$ & $5.7 \%$ & $5.3 \%$ & $7.3 \%$ & $10.3 \%$ & $12.1 \%$ & $13.8 \%$ \\
\hline Public Admin. & $1.6 \%$ & $4.8 \%$ & $5.7 \%$ & $6.1 \%$ & $6.5 \%$ & $5.9 \%$ & $5.4 \%$ \\
\hline Sample Size & 37794 & 39070 & 39091 & 38394 & 44394 & 38948 & 39471 \\
\hline
\end{tabular}

Notes: (1) The sample consists of male nonagricultural workers (ages 16-64) who worked at least 15 hours in the week prior to the survey date and at least 14 weeks in the year prior to survey date. We do not impose hours and weeks worked restrictions in 1910 due to data limitations. (2) The self-employment rate is the percentage of all those working who are self-employed.

(3) Estimates for 1990 are calculated using weights provided by the Census. 
Table 4

Decompositions of Aggregate White Self-Employment Rate

\begin{tabular}{rrrrrrrr}
$1910-$ & $1940-$ & $1950-$ & $1960-$ & $1970-$ & $1980-$ & $1910-$ & $1970-$ \\
1940 & 1950 & 1960 & 1970 & 1980 & 1990 & 1970 & 1990 \\
\hline
\end{tabular}

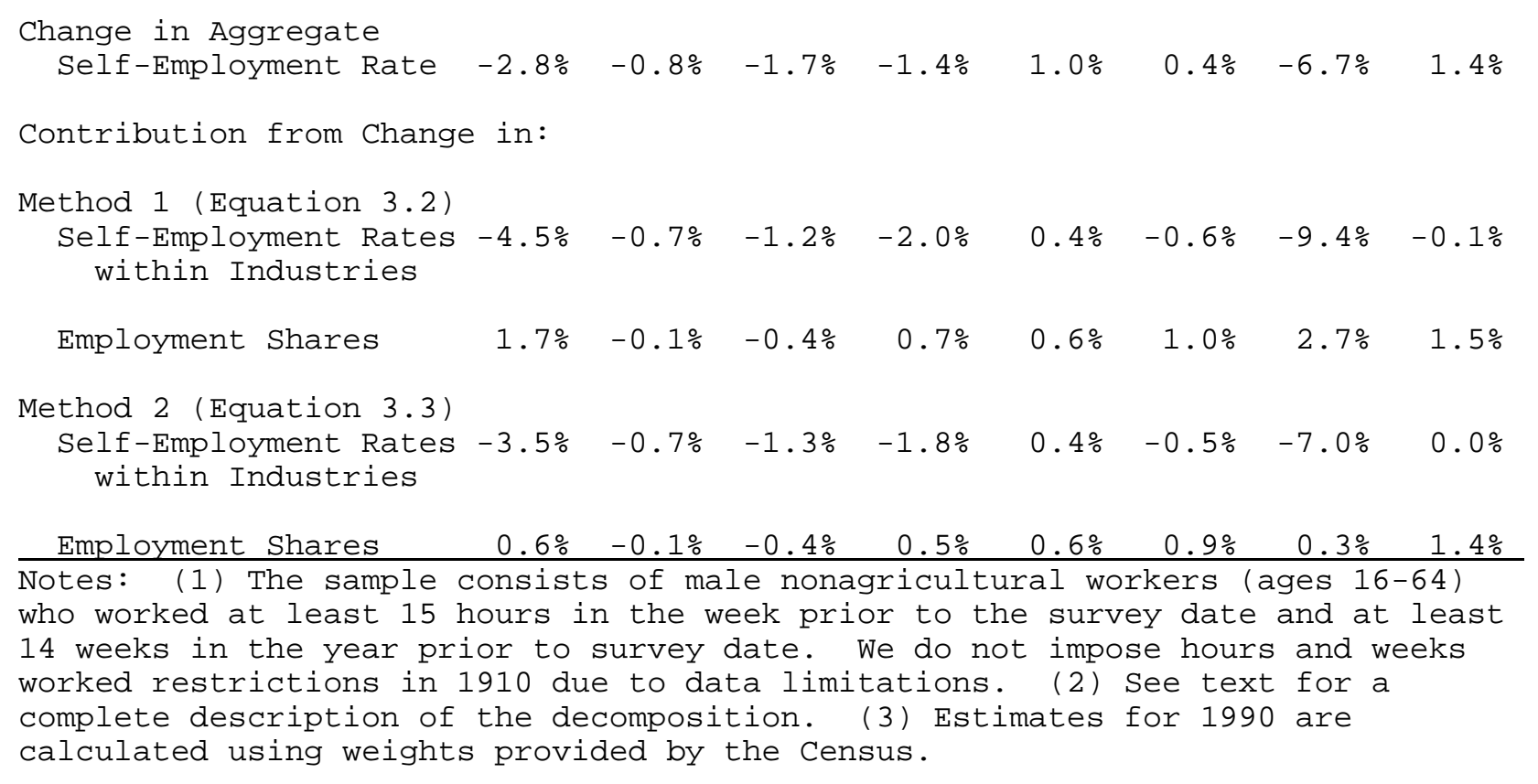


Table 5

Industry Decomposition of Aggregate White Self-Employment Rate (1970-1990)

\begin{tabular}{|c|c|c|c|c|c|}
\hline Industry & $\begin{array}{l}\text { Method } 1 \\
\text { Contributi } \\
\text { Change in: } \\
\text { Self-Empl. } \\
\text { Rate }\end{array}$ & $\begin{array}{l}\text { Equation 3.5) } \\
\text { on from } \\
\text { Employment } \\
\text { Share }\end{array}$ & $\begin{array}{c}\text { Method } 2 \\
\text { Contribut } \\
\text { Change in } \\
\text { Self-Empl. } \\
\text { Rate }\end{array}$ & $\begin{array}{c}\text { Employment } \\
\text { Share }\end{array}$ & $\begin{array}{l}\text { Net Contribution } \\
\text { from Industry } \\
\text { (Equation } 3.4 \text { ) }\end{array}$ \\
\hline Mining & $-0.00 \div$ & $0.02 \%$ & $-0.00 \%$ & $0.02 \%$ & $0.01 \%$ \\
\hline Construction & $0.45 \%$ & $0.20 \%$ & $0.54 \%$ & $0.11 \%$ & $0.65 \%$ \\
\hline Manufacturing & $0.56 \%$ & $0.66 \%$ & $0.40 \%$ & $0.81 \%$ & $1.21 \%$ \\
\hline Transportation & $0.14 \%$ & $-0.04 \%$ & $0.16 \%$ & $-0.05 \%$ & $0.10 \%$ \\
\hline Trade & $-1.04 \%$ & $0.00 \%$ & $-1.07 \%$ & $0.03 \%$ & $-1.04 \%$ \\
\hline FIRE & $0.27 \%$ & $0.09 \%$ & $0.34 \%$ & $0.01 \%$ & $0.36 \%$ \\
\hline Bus. and Repair & $-0.07 \%$ & $0.24 \%$ & $-0.11 \%$ & $0.29 \%$ & $0.17 \%$ \\
\hline Personal Serv. & $-0.16 \%$ & $-0.04 \%$ & $-0.13 \%$ & $-0.07 \%$ & $-0.20 \%$ \\
\hline Ent. and Rec. & $-0.05 \%$ & $0.01 \%$ & $-0.11 \%$ & $0.07 \%$ & $-0.04 \%$ \\
\hline Professional & $-0.08 \%$ & $0.11 \%$ & $-0.11 \%$ & $0.14 \%$ & $0.03 \%$ \\
\hline Public Admin. & $0.00 \%$ & $0.13 \%$ & $0.00 \%$ & $0.13 \%$ & $0.13 \%$ \\
\hline Total & $0.02 \%$ & $1.37 \%$ & $-0.09 \%$ & $1.48 \%$ & $1.39 \%$ \\
\hline
\end{tabular}

Notes: (1) The sample consists of male nonagricultural workers (ages 16-64) who worked at least 15 hours in the week prior to the survey date and at least 14 weeks in the year prior to survey date. We do not impose hours and weeks worked restrictions in 1910 due to data limitations. (2) See text for a complete description of the decomposition. (3) Estimates for 1990 are calculated using weights provided by the Census. 
Table 6

Black Self-Employment Rates and Employment Shares by Industry

\begin{tabular}{|c|c|c|c|c|c|c|c|}
\hline Industry & 1910 & 1940 & 1950 & 1960 & 1970 & 1980 & 1990 \\
\hline \multicolumn{8}{|c|}{ Self-Employment Rates } \\
\hline Mining & $0.7 \%$ & $1.2 \%$ & $0.8 \%$ & $0.7 \%$ & $1.6 \%$ & $0.7 \%$ & $1.7 \%$ \\
\hline Construction & $11.7 \%$ & $10.2 \%$ & $6.1 \%$ & $8.8 \%$ & $9.8 \%$ & $8.7 \%$ & $9.9 \%$ \\
\hline Manufacturing & $1.1 \%$ & $1.1 \%$ & $0.4 \%$ & $0.6 \%$ & $0.9 \%$ & $0.8 \%$ & $1.0 \%$ \\
\hline Transportation & $1.6 \%$ & $4.7 \%$ & $3.2 \%$ & $3.6 \%$ & $3.8 \%$ & $2.7 \%$ & $4.1 \%$ \\
\hline Trade & $16.3 \%$ & $10.5 \%$ & $8.1 \%$ & $4.9 \%$ & $5.0 \%$ & $4.6 \%$ & $3.5 \%$ \\
\hline FIRE & $3.7 \%$ & $4.2 \%$ & $5.3 \%$ & $2.9 \%$ & $3.4 \%$ & $3.9 \%$ & $5.9 \%$ \\
\hline Bus. and Repair & $24.0 \%$ & $15.6 \%$ & $13.1 \%$ & $15.6 \%$ & $14.0 \%$ & $13.7 \%$ & $11.5 \%$ \\
\hline Personal Serv. & $9.2 \%$ & $7.9 \div$ & $7.9 \%$ & $9.6 \%$ & $12.1 \%$ & $11.5 \%$ & $11.3 \%$ \\
\hline Ent. and Rec. & $11.8 \%$ & $8.7 \%$ & $5.2 \%$ & $4.9 \%$ & $4.8 \%$ & $8.0 \%$ & $8.0 \%$ \\
\hline Professional & $11.9 \%$ & $8.7 \%$ & $5.9 \%$ & $3.7 \%$ & $3.5 \%$ & $3.3 \%$ & $3.4 \%$ \\
\hline Public Admin. & $0.0 \%$ & $0.0 \%$ & $0.0 \%$ & $0.0 \%$ & $0.0 \%$ & $0.0 \%$ & $0.0 \%$ \\
\hline Total & $6.0 \%$ & $6.0 \%$ & $4.1 \%$ & $3.8 \%$ & $3.9 \%$ & $3.5 \%$ & $4.1 \%$ \\
\hline \multicolumn{8}{|l|}{ Employment Shares } \\
\hline Mining & $6.4 \%$ & $2.9 \%$ & $1.8 \%$ & $0.6 \%$ & $0.5 \%$ & $0.8 \%$ & $0.5 \%$ \\
\hline Construction & $10.6 \%$ & $8.9 \%$ & $10.4 \%$ & $10.7 \%$ & $9.6 \%$ & $8.0 \%$ & $7.9 \%$ \\
\hline Manufacturing & $28.0 \%$ & $27.9 \%$ & $33.3 \%$ & $33.0 \%$ & $34.7 \%$ & $31.1 \%$ & $22.9 \%$ \\
\hline Transportation & $21.6 \%$ & $12.0 \%$ & $12.6 \%$ & $10.4 \%$ & $10.6 \%$ & $13.6 \%$ & $14.2 \%$ \\
\hline Trade & $11.6 \%$ & $17.5 \%$ & $17.0 \%$ & $16.7 \%$ & $15.3 \%$ & $14.8 \%$ & $17.7 \%$ \\
\hline FIRE & $1.9 \%$ & $3.3 \%$ & $2.2 \%$ & $2.2 \%$ & $2.8 \%$ & $3.7 \%$ & $4.6 \%$ \\
\hline Bus. and Repair & $1.1 \%$ & $2.8 \%$ & $3.1 \%$ & $3.1 \%$ & $3.5 \%$ & $4.5 \%$ & $6.0 \%$ \\
\hline Personal Serv. & $13.4 \%$ & $15.0 \%$ & $7.9 \%$ & $6.2 \%$ & $3.7 \%$ & $2.0 \%$ & $2.5 \%$ \\
\hline Ent. and Rec. & $0.8 \%$ & $1.6 \%$ & $1.1 \%$ & $1.2 \%$ & $0.8 \%$ & $0.9 \%$ & $1.4 \%$ \\
\hline Professional & $3.8 \%$ & $5.3 \%$ & $5.2 \%$ & $8.1 \%$ & $10.2 \%$ & $13.1 \%$ & $14.8 \%$ \\
\hline Public Admin. & $0.8 \%$ & $2.8 \%$ & $5.3 \%$ & $7.8 \%$ & $8.1 \%$ & $7.5 \%$ & $7.5 \%$ \\
\hline Sample Size & 4369 & 14421 & 6876 & 24882 & 35627 & 37484 & 37190 \\
\hline \multicolumn{8}{|c|}{ Black/White Self-Employment Rate Ratio } \\
\hline Mining & 0.191 & 0.244 & 0.209 & 0.232 & 0.296 & 0.149 & 0.329 \\
\hline Construction & 0.562 & 0.478 & 0.320 & 0.445 & 0.569 & 0.409 & 0.449 \\
\hline Manufacturing & 0.192 & 0.340 & 0.111 & 0.249 & 0.348 & 0.236 & 0.239 \\
\hline Transportation & 0.551 & 0.736 & 0.623 & 0.797 & 0.916 & 0.564 & 0.709 \\
\hline Trade & 0.434 & 0.387 & 0.304 & 0.215 & 0.296 & 0.302 & 0.305 \\
\hline FIRE & 0.138 & 0.285 & 0.329 & 0.213 & 0.269 & 0.272 & 0.317 \\
\hline Bus. and Repair & 0.612 & 0.506 & 0.437 & 0.539 & 0.590 & 0.538 & 0.524 \\
\hline Personal Serv. & 0.260 & 0.268 & 0.268 & 0.274 & 0.376 & 0.383 & 0.479 \\
\hline Ent. and Rec. & 0.451 & 0.512 & 0.361 & 0.267 & 0.233 & 0.403 & 0.606 \\
\hline Professional & 0.282 & 0.313 & 0.287 & 0.193 & 0.229 & 0.225 & 0.231 \\
\hline Public Admin. & 0.356 & 0.433 & 0.313 & 0.338 & 0.387 & 0.319 & 0.359 \\
\hline
\end{tabular}

Notes: (1) The sample consists of male nonagricultural workers (ages 16-64) who worked at least 15 hours in the week prior to the survey date and at least 14 weeks in the year prior to survey date. We do not impose hours and weeks worked restrictions in 1910 due to data limitations. (2) The self-employment rate is the percentage of all those working who are self-employed.

(3) Estimates for 1990 are calculated using weights provided by the Census. 
Table 7

Decomposition of Changes in the Racial Self-Employment Rate Gap (1940-1990)

\begin{tabular}{|c|c|c|c|c|c|}
\hline & $\begin{array}{r}1940- \\
1950 \\
\end{array}$ & $\begin{array}{r}1950- \\
1960 \\
\end{array}$ & $\begin{array}{r}1960- \\
1970 \\
\end{array}$ & $\begin{array}{r}1970- \\
1980 \\
\end{array}$ & $\begin{array}{r}1980- \\
1990 \\
\end{array}$ \\
\hline \multicolumn{6}{|l|}{ Initial Year } \\
\hline White Self-Empl. Rate & 13.818 & 13.053 & 11.091 & 9.983 & 10.703 \\
\hline Black Self-Empl. Rate & 6.137 & 4.110 & 3.633 & 3.859 & 3.309 \\
\hline Gap: White-Black Rate & 7.681 & 8.942 & 7.458 & 6.124 & 7.394 \\
\hline Decadal Change in Gap & 1.261 & -1.485 & -1.334 & 1.270 & 0.327 \\
\hline \\
\hline \multicolumn{6}{|l|}{ (i) Characteristics Effect } \\
\hline Age & -0.189 & -0.128 & -0.104 & 0.078 & -0.003 \\
\hline Marriage/Children & -0.011 & 0.001 & -0.058 & -0.041 & 0.030 \\
\hline Education & 0.181 & 0.146 & 0.113 & -0.090 & -0.067 \\
\hline Region & 0.390 & 0.192 & 0.142 & -0.028 & -0.032 \\
\hline \multicolumn{6}{|c|}{ (ii) Characteristics-Race Interaction } \\
\hline Age & 0.281 & 0.323 & -0.118 & -0.592 & 0.370 \\
\hline Marriage/Children & 0.241 & 0.130 & 0.008 & -0.067 & -0.073 \\
\hline Education & -0.091 & 0.057 & 0.101 & 0.402 & 0.293 \\
\hline Region & -0.312 & -0.101 & -0.049 & 0.043 & 0.026 \\
\hline \multicolumn{6}{|c|}{ (iii) Coefficients-Race Interaction } \\
\hline Age & -0.184 & 0.016 & -0.054 & -0.038 & 0.027 \\
\hline Marriage/Children & 0.088 & -0.041 & -0.039 & 0.023 & 0.047 \\
\hline Education & 0.168 & -0.487 & -0.143 & -0.197 & -0.227 \\
\hline Region & -0.132 & -0.105 & 0.071 & 0.161 & -0.131 \\
\hline (iv) Coefficients Effect & 0.832 & -1.487 & -1.203 & 1.615 & 0.068 \\
\hline \multicolumn{6}{|c|}{$\begin{array}{l}\text { Notes: (1) The sample consists of male nonagricultural workers (ages 16-64) } \\
\text { who worked at least } 15 \text { hours in the week prior to the survey date and at least } \\
14 \text { weeks in the year prior to survey date. (2) See text for a complete } \\
\text { description of each component of the decomposition. (3) The black and white } \\
\text { self-employment rates in } 1990 \text { are } 4.1 \text { and } 11.8 \text { percent, respectively. }\end{array}$} \\
\hline
\end{tabular}


Table 8

Mean and Median Household Net Worth by Race (1990 Dollars)

Mean Net Worth

Black/White

Year Source Black

1962

1984

1988

1991

rces: (A) Tabulations using

(B) The Survey of Income and Program Participation reported in U.S. Department of Commerce, Household Wealth and Asset Ownership.

Median Net Worth Black/White Black White Ratio

$\begin{array}{llll}0.174 & 3927 & 38116 & 0.103 \\ 0.234 & 4273 & 49229 & 0.087 \\ 0.233 & 4606 & 47815 & 0.096 \\ 0.249 & 4418 & 42615 & 0.104\end{array}$

$\begin{array}{ll}19314 & 111 \\ 25462 & 108 \\ 26130 & 111 \\ 26716 & 107 \\ \text { bulations us } \\ \text { ted in Avery } \\ \text { Ocipation r }\end{array}$


Table 9

CPS Male Self-Employment Rates

March CPS 1966-1996, Outgoing Rotation Group (ORG) Data 1984-1996

\begin{tabular}{|c|c|c|c|c|c|c|}
\hline \multirow[b]{2}{*}{ Year } & \multicolumn{2}{|c|}{ White Rates } & \multicolumn{2}{|c|}{ Black Rates } & \multicolumn{2}{|c|}{ Black/White Ratio } \\
\hline & March & ORG & March & ORG & March & ORG \\
\hline 1966 & 0.08267 & & 0.04265 & & 0.51591 & \\
\hline 1967 & 0.08102 & & 0.03571 & & 0.44069 & \\
\hline 1968 & 0.08423 & & 0.03888 & & 0.46161 & \\
\hline 1969 & 0.07852 & & 0.03640 & & 0.46359 & \\
\hline 1970 & 0.08112 & & 0.03514 & & 0.43312 & \\
\hline 1971 & 0.07757 & & 0.04572 & & 0.58944 & \\
\hline 1972 & 0.07979 & & 0.03544 & & 0.44419 & \\
\hline 1973 & 0.07751 & & 0.02832 & & 0.36535 & \\
\hline 1974 & 0.07385 & & $\underline{0.03006}$ & & $\underline{0.40708}$ & \\
\hline 1975 & 0.10686 & & 0.02678 & & 0.25056 & \\
\hline 1976 & 0.10977 & & 0.03585 & & 0.32661 & \\
\hline 1977 & 0.11241 & & 0.04633 & & 0.41216 & \\
\hline 1978 & 0.11526 & & 0.03563 & & 0.30909 & \\
\hline 1979 & 0.12244 & & 0.03891 & & 0.31776 & \\
\hline 1980 & 0.11984 & & 0.03071 & & 0.25623 & \\
\hline 1981 & 0.12380 & & 0.04992 & & 0.40320 & \\
\hline 1982 & 0.13165 & & 0.03803 & & 0.28889 & \\
\hline 1983 & 0.12762 & & 0.03776 & & 0.29589 & \\
\hline 1984 & 0.12792 & 0.13429 & 0.03149 & 0.04982 & 0.24615 & 0.37097 \\
\hline 1985 & 0.12357 & 0.13161 & 0.04269 & 0.04579 & 0.34548 & 0.34795 \\
\hline 1986 & 0.12487 & 0.13263 & 0.04555 & 0.04993 & 0.36480 & 0.37645 \\
\hline 1987 & 0.12674 & 0.13238 & 0.03403 & 0.04892 & 0.26852 & 0.36956 \\
\hline 1988 & 0.12660 & 0.13371 & 0.04134 & 0.04988 & 0.32653 & 0.37305 \\
\hline 1989 & 0.12589 & 0.13395 & 0.04723 & 0.04798 & 0.37517 & 0.35819 \\
\hline 1990 & 0.12836 & 0.13316 & 0.05546 & 0.05469 & 0.43205 & 0.41074 \\
\hline 1991 & 0.12752 & 0.13554 & 0.04445 & 0.05365 & 0.34856 & 0.39582 \\
\hline 1992 & $\underline{0.13056}$ & 0.13539 & $\underline{0.04894}$ & 0.05151 & $\underline{0.37485}$ & 0.38046 \\
\hline 1993 & $\overline{0.12265}$ & $\underline{0.14009}$ & $\overline{0.05616}$ & $\underline{0.04873}$ & $\overline{0.45790}$ & $\underline{0.34785}$ \\
\hline 1994 & 0.12070 & 0.12903 & 0.04515 & 0.05867 & 0.37408 & 0.45472 \\
\hline 1995 & 0.11930 & 0.12770 & 0.05355 & 0.05554 & 0.44885 & 0.43491 \\
\hline 1996 & 0.12107 & 0.12524 & 0.05583 & 0.05783 & 0.46117 & 0.46176 \\
\hline 1997 & 0.11749 & & 0.04391 & & 0.37376 & \\
\hline
\end{tabular}

Notes: (1) The sample consists of male non-agricultural workers ages 16-64 who worked at least 15 hours last week (March and ORG) and at least 14 weeks during the year (March only). (2) The lines represent changes in survey methodology as described in the text. (3) All rates are calculated using sample weights. 
Figure 1

Self-Employment Rates by Race

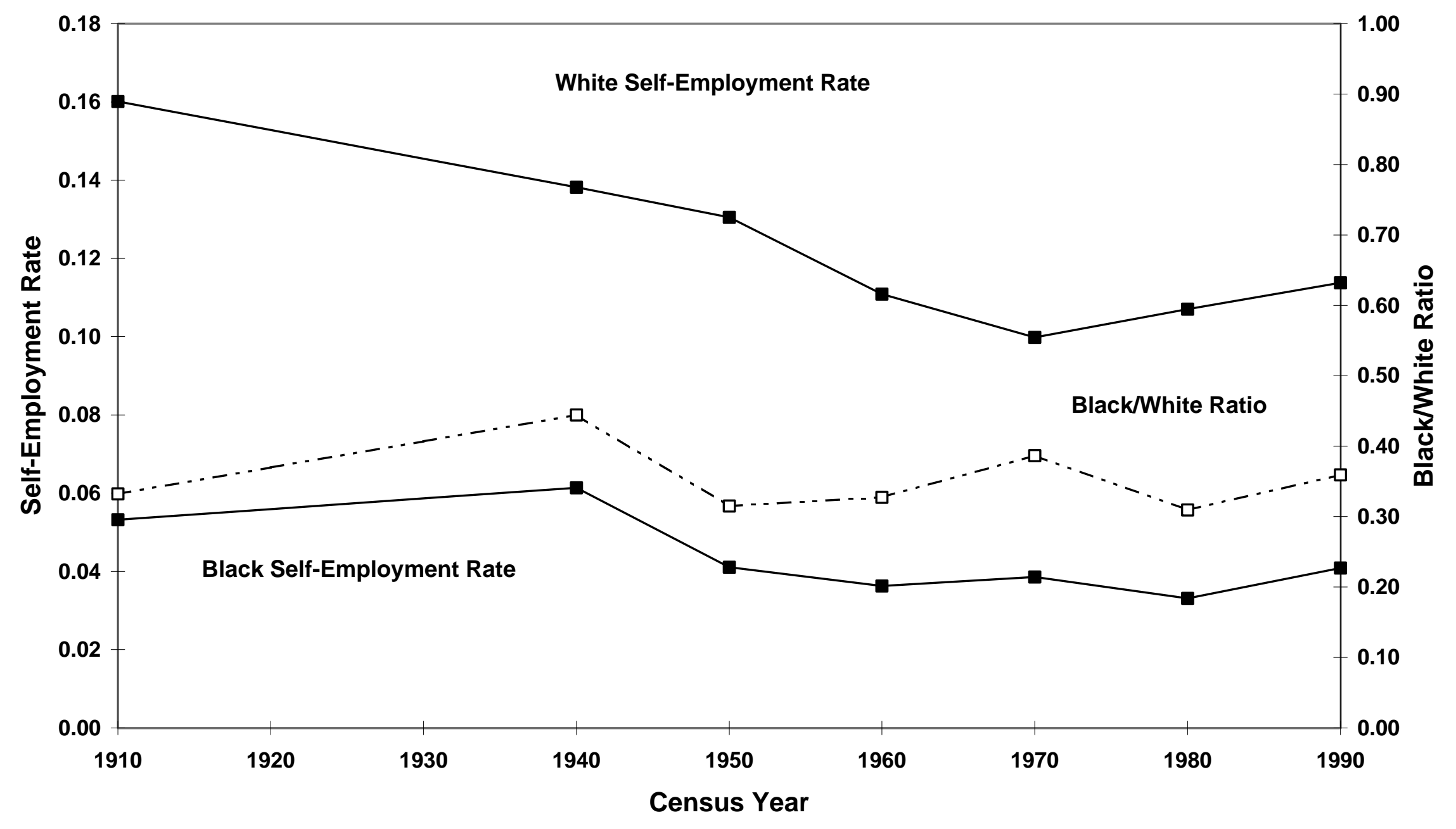


Figure 2

Self-Employment Rates by Race

(Full-Time, Full-Year Workers)

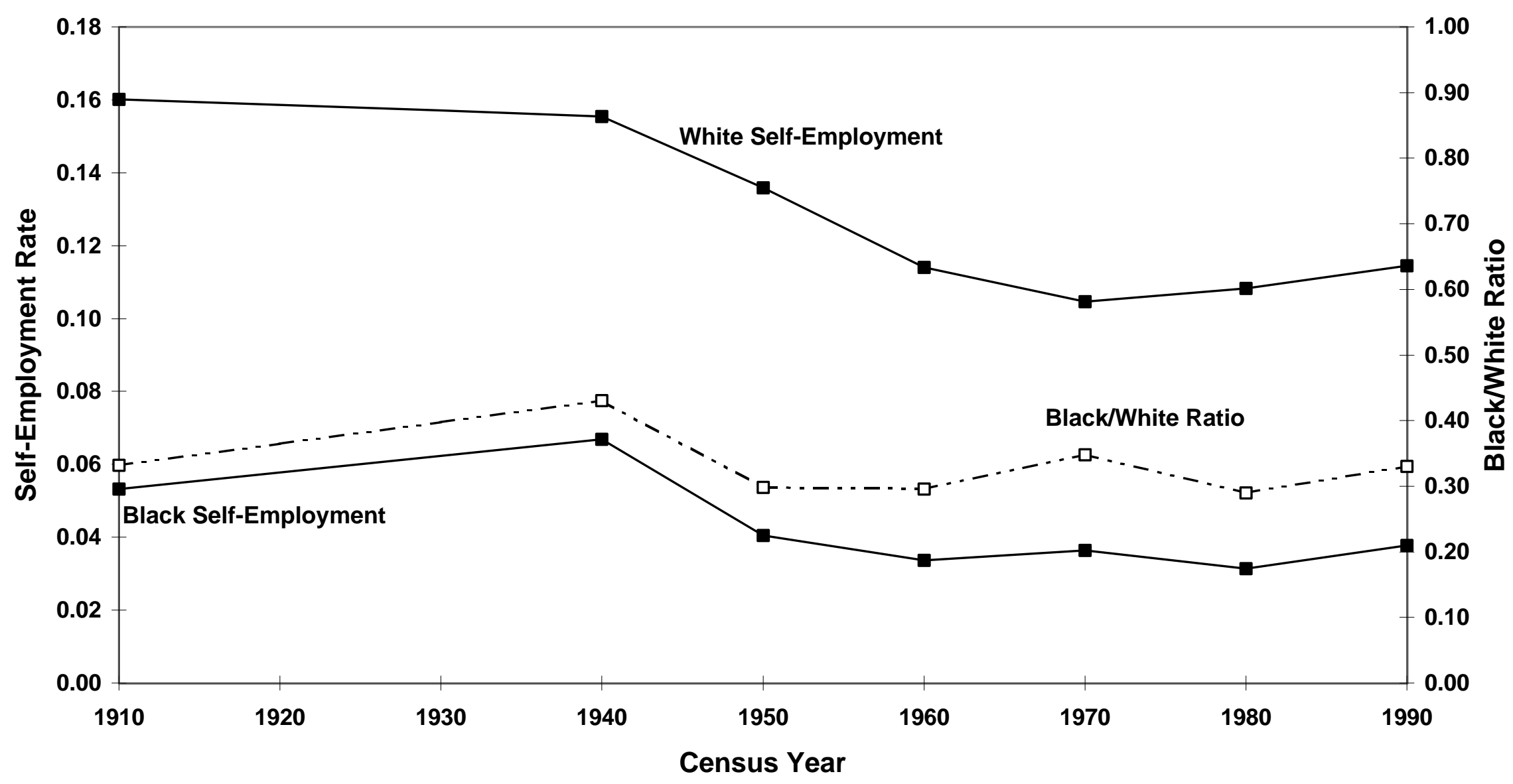


Figure 3

White Self-Employment Rate and Federal Tax Rates

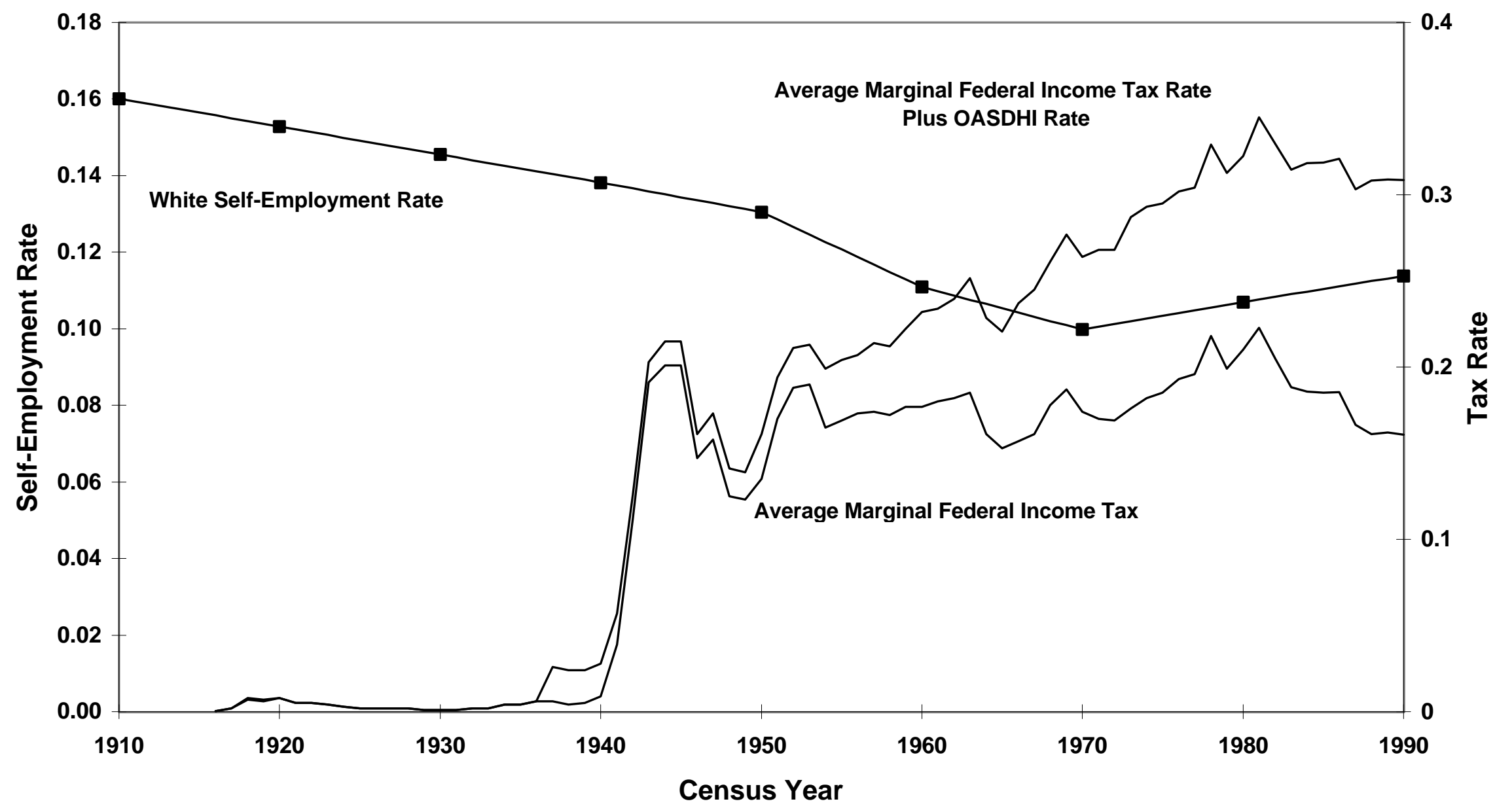


Figure 4

White Self-Employment Rates and Social Security (OASI) Benefit Levels

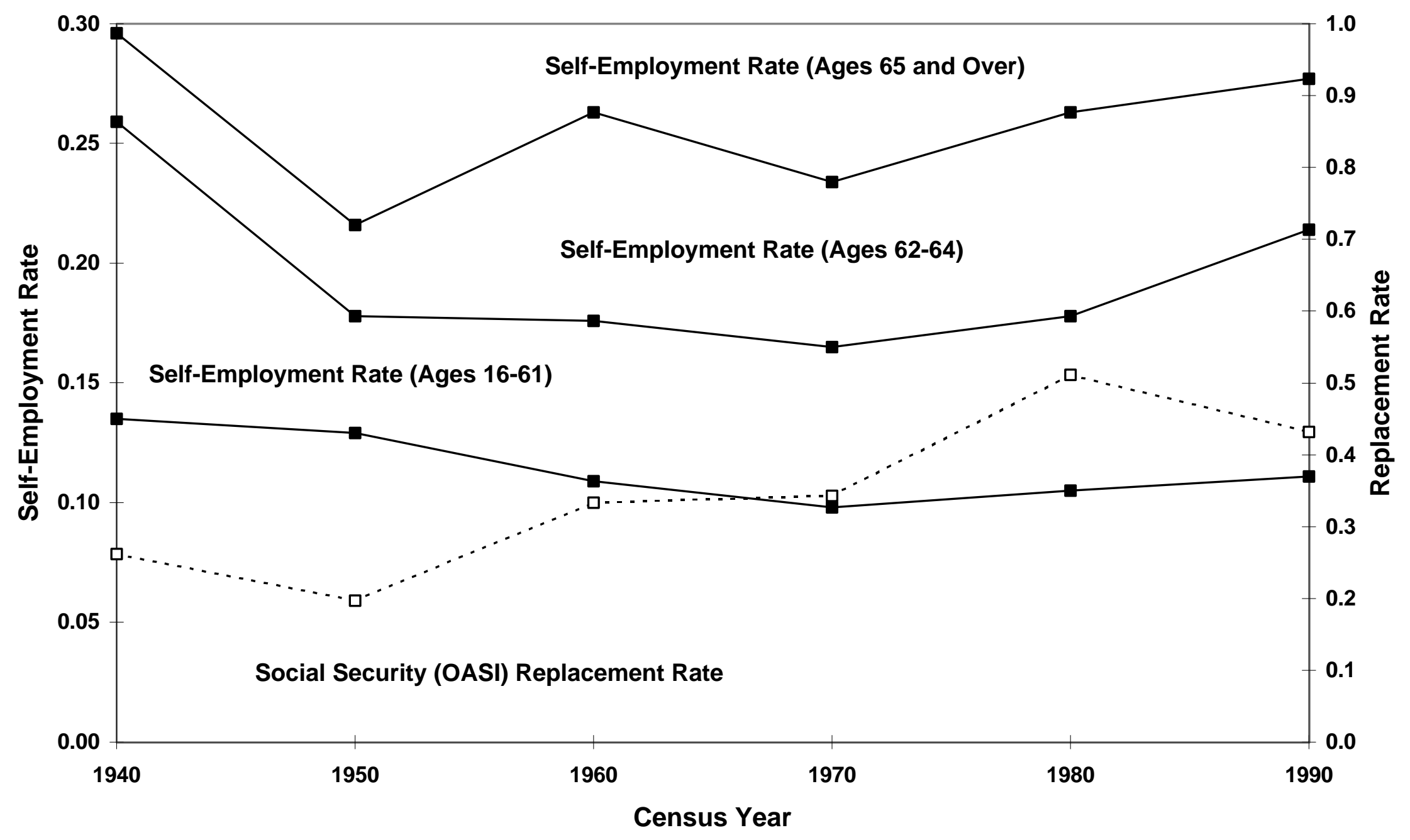


Figure 5

Self-Employment Rates by Immigrant Status

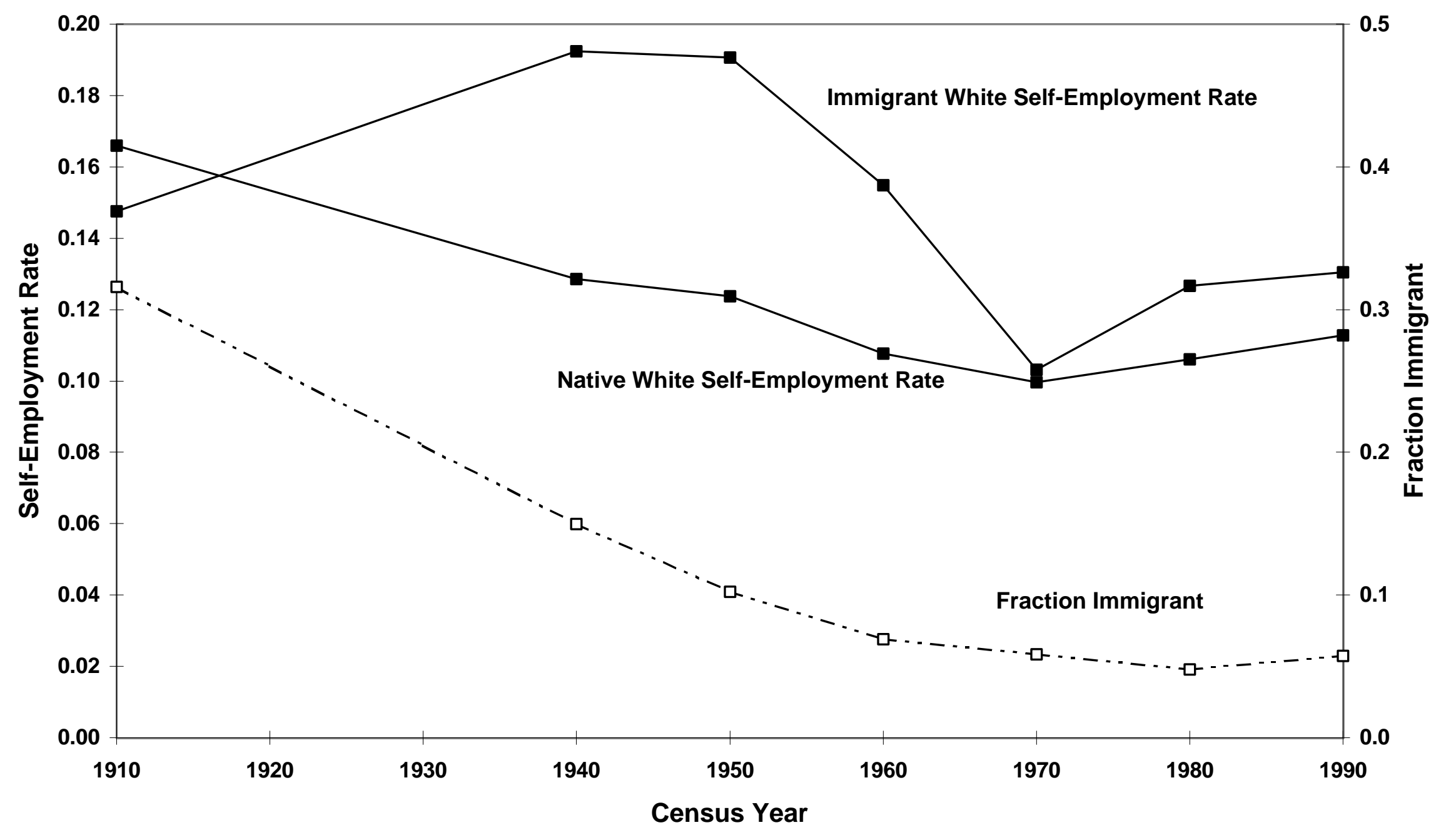


Figure 6

Black/White Self-Employment Rate Ratio by Age Cohort

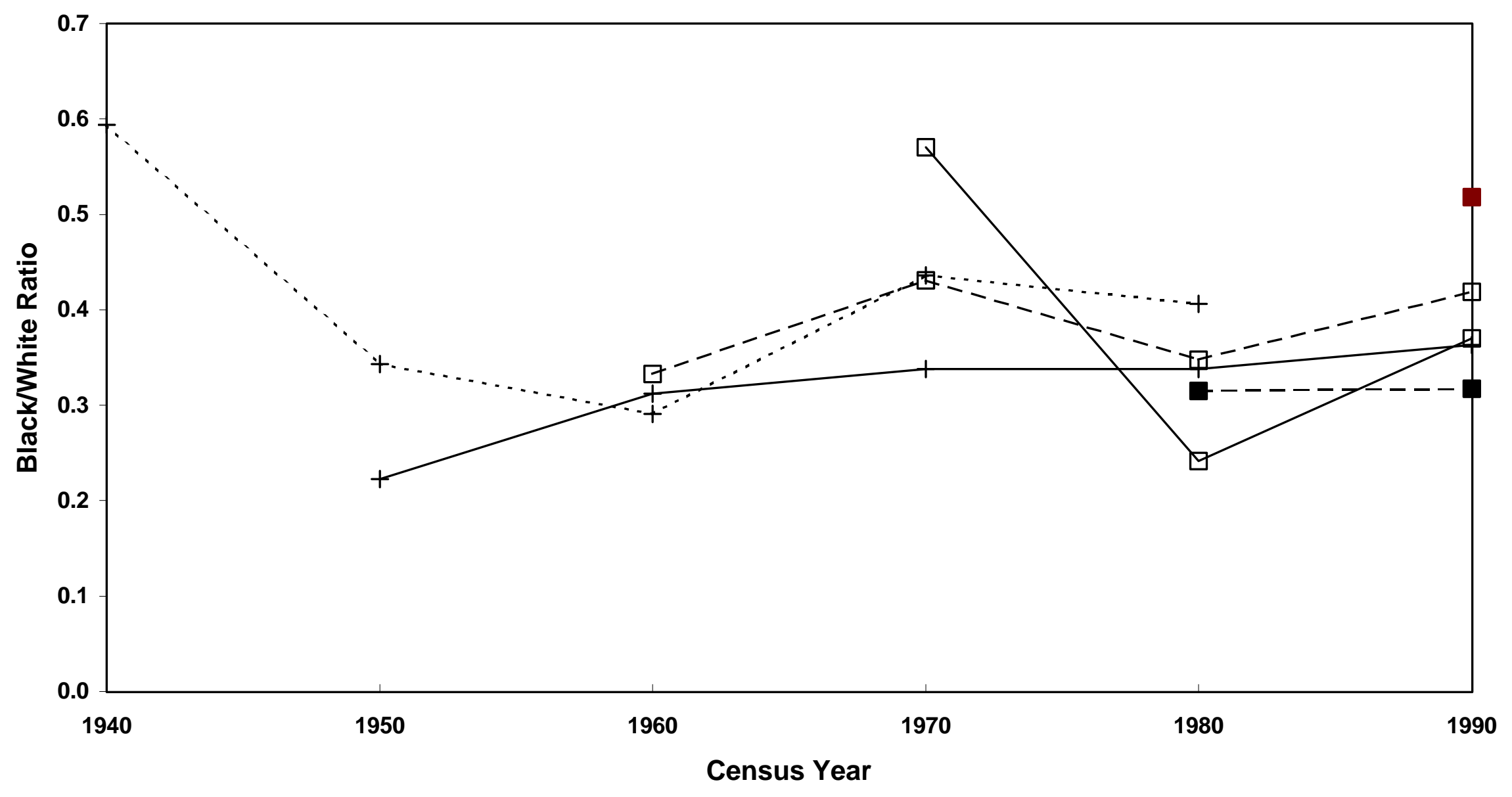

$\longrightarrow$ - Ages 15-24 in $1990-\square-$ Ages 15-24 in $1980 \square \square$ - Ages 15-24 in 1970 - - A Ages 15-24 in 1960 —_Ages 15-24 in 1950 - - + - Ages 15-24 in 1940 